\title{
THE EVOLUTION IN AND INTERNATIONAL CONVERGENCE OF THE DOCTRINE OF SPECIFIC PERFORMANCE IN THREE TYPES OF STATES
}

\author{
Robert Bejesky*
}

\section{INTRODUCTION}

Pacta sunt servanda is the universally accepted notion ${ }^{1}$ that contract promises must be kept and that affirmative actions to ensure satisfactory completion of obligations occurs. ${ }^{2}$ Even though every legal system emphasizes that breaching a freely negotiated contract is dishonorable ${ }^{3}$ and requires a remedy, the degree that law insures strict adherence to the precise definition of a contract's original terms has varied across countries. ${ }^{4}$ This article historically evaluates the relative degree of government interest ${ }^{5}$ in ensuring that contractual relations among independent economic actors maintain integrity by examining both government ideology toward the private sector and the derivative authority of the judiciary as an independent actor that

* J.D. Thomas M. Cooley Law School, LL.M. Georgetown University Law Center, MAE Michigan, Ph.D. Candidate Political Science, University of Michigan. Professor Bejesky currently teaches International and Comparative Law at the Cooley Law School and is an Adjunct Professor of Political Science at Alma College. He previously worked for the InterAmerican Development Bank in Washington D.C.. Professor Bejesky publishes on the area of intermational economic integration and its impact on comparative law.

1. This is expressed at the international level. Vienna Convention on the Law of Treaties, May 23, 1969, U.N. Doc. A/Conf. 39/27, at 289 (1969), 1155 U.N.T.S. 331, art. 26. Customary international law is formed "as evidence of a general practice accepted as law." Statute of the International Court of Justice, June 26, 1945, 59 Stat. 1031, T.S. No. 993, art. 38(b). For establishing customary international law, see generally DAVID J. BEDERMAN, INTERNATIONAL LAW FRAMEWORKS, 14-24 (2001).

2. See Walter Neitzel, Specific Performance, Injunctions, and Damages in the German Law, 22 HARV L. REv. 161, 165 (1909).

3. See generally Charles Fried, Contract as Promises: A Theory of CONTRACTUAL Obligations (1981); see John RAWLS, A THEORY OF JUSTICE 344-50 (1971).

4. This difference was said to be an "abyss" between Continental and Anglo-American legal systems. See generally Ernst Rabel, A Draft of an International Law of Sales, 5 U. CHI. L. REV. 559 (1938). See also JOHN O. HONNOLD, UNIFORM LAW FOR INTERNATIONAL SALES UNDER THE 1980 UNITED NATIONS CONVENTION 274-77 (1991).

5 . While the theme of this work is historical and evolutionary in nature, both current governments and the private sector have keen interests in this issue since stable contractual relations are vital to a healthy economy and the political self-interest of those in power, while private sector businesses utilize contracts to lessen risks and increase their ability to make foresighted business projections since the expectation that effectual remedial measures will be dispensed can impel the bargaining and contract consummation process. See HENRY SIDGWICK, ELEMENTS OF POLITICS 78 (1891). At extremes, complete trust may exist between parties or promises could be perceived by the parties as "empty shams." See IMMANUEL KANT, GROUNDWORK OF THE METAPHYSIC OF MORALS 90 (H. Paton trans., 1964). 
can be summoned to resolve contract disputes. Influencing the persona of this doctrine are key moments in a country's history that have circumscribed the acceptable legal nexus between government and the private sector, but government institutions and concomitant ideology have evolved and/or taken abrupt deviations because of internal and external political and economic dynamics. The judiciary's role as a private sector dispute settler emanates from and is philosophically consistent with this ideological framework.

The article is broken down into five substantive sections that consider the legal dynamics of six countries divided into three categories: the United States and Britain (reactive states); France and Germany (semi-active states); and Russia and China (activist states). The second and third sections respectively establish the theoretical framework and rationale for country choices, and describe the long-lived specific performance rules in these countries. The fourth part characterizes the historical ideology of the surveyed states and the derivative role of the judiciary in granting coercive relief, while the fifth section considers how internal and external economic and social dynamics have induced changes in government ideology and deviations in the historical specific performance rule frameworks.

\section{THEORETICAL FRAMEWORK}

\section{A. Dispute Settlement in an Archaic Society}

Without the existence of a government in a territory, there would be no formal dispute settlement mechanism to adjudicate rights. Instead, dispute resolution would be predicated on either, self-help, informal mediation forms, or both. ${ }^{6}$ Assume there are two people who consummate an oral contract to trade potatoes for a chicken, but the owner of the chicken later decides to not provide it to the potato farmer. The potato farmer certainly does not have to confer his potatoes unless he receives the chicken, but what if the potato farmer was veritably dependent on the trade? Should he have a right to attain the chicken against the will of its current owner? If the inhabitants of this society live in peace and harmony, they would presumably have informal and respected community-wide dispute settlement norms. ${ }^{7}$ Accepted community remedial norms might permit one to unilaterally take the locus of the agreement without the authorization or coercive power of a governance authority, which would be a form of "self-help." However, even before selfhelp is exercised, a mutually respected and independent mediator ${ }^{8}$ might

6. This would normally consist of both parties agreeing upon permitting one or more respected individuals, probably elders, that are perceived as being independent of the interests of either party, to act in the capacity of what today is considered a mediator or arbitrator.

7. This assumes that there are no codified norms established by a governance unit.

8. See generally MARTin ShaPIRo, Courts: A COMPARATIVE AND POLITICAL ANALYSIS (1981). 
become involved to "buy off a feud" to maintain peace and harmony in society ${ }^{9}$ by structuring a remedial decision within the parameters of community norms. This would be a primitive form of adjudication employed to "define the limits of self-help" and to validate legitimate community conduct under the facts of the dispute.

When government does exist and law is established, a position is taken on contractual relations establishing norms on how disputes should be resolved so that actions relating to contract performance can more easily be deemed appropriate or inappropriate. If there is a deviation from those contractual norms, the executive and police force can enforce rules and protect the contractual expectations of parties to a contract, but normally only after legitimate rights and breach of obligations have been validated by the judiciary.

\section{B. Emergence of Institutionalized Law Premised on Governance Ideology}

The assumption implicit in this article relating to the evolution of government institutions is that when institutions of law are established, they will reflect state ideology and relationships in society." "Law reflects to a large degree the civilization [sic] of those that live under it," its development is often based on "the outlook of the age,"12 and the "structure of the law is that we can trace every legal provision right back to its ideological and economic roots."13 There is consistency between ideological movements and current code provisions ${ }^{14}$ and a nexus between legal proceedings and "dominant views on the role of government in society."15 If "[l]aw is inseparable with the theory of the state"16 and reflects the way of life of people in a society, there will be consistency between positive legal institutions ${ }^{17}$ and culture, ${ }^{18}$ and in terms of contractual relations, the judiciary and its mandate

9. See John P. Dawson, Specific Relief in France and Germany, 57 MICH. L. REV. 495, 497 (1959).

10. See id. This would particularly be the case when complete transparency in acceptable disputes settlement norms does not exist.

11. See Hans KelSEN, THE Communist Theory of LAW 10 (1955); see generally Mirjan R. Damaska, The FaCes of Justice and State Authority: A Comparative APPROACH TO THE LEGAL PROCESS (1986).

12. HAROLD POTTER, HISTORICAL INTRODUCTION TO ENGLISH LAW 6 (2nd ed. 1943).

13. See Bernhard Grossfeld, Money Sanctions for Breach of Contract in a Communist Economy, 72 YALE L.J. 1326, 1345 (1963).

14. See SChlesinger et AL., COMPaRATIVe Law CASES: TeXt Materials 731 (6th ed. 1998).

15. DAMASKA, supra note 11 , at 10.

16. KELSEN, supra note 11 , at 1.

17. "Positive legal institutions" refers to progressive government norms of acceptable societal conduct.

18. While this article is not concerned with cultural attributes of legal evolution, this too could be another factor for analysis since institutions can affect culture and culture can affect the adoption of new legal institutions. See generally RONALD INGLEHART, MODERNIZATION 
to grant remedial relief should derive from and be consistent with this structure.

The framework of this contention is premised on a work by Mirjan R. Damaska $^{19}$ that characterized judicial systems and law not according to historical distinctions of civil law, common law, and socialist law, but according to the degree that government involved itself in the inner-workings of society and the economy as balanced against the rights of the individual. ${ }^{20}$ At one extreme, a reactive government aspires only to "maintain the social equilibrium and merely provide a framework for social self-management and individual self-definition," while the other extreme, an active government, seeks to "manage the lives of people and steer society"21 and promote the "moral betterment of its citizens." the United States and Britain (reactive states), ${ }^{24}$ France and Germany (semiactive states), ${ }^{25}$ and the former Soviet Union and China (active states) ${ }^{26}$-can be located along a continuum that contemplates the degree of individualism versus government authority within the context of property rights and freedom of contract.

At the essence of enduring and fervent altercations involving the posture that government should champion with regard to contract and property rights

AND POSTMOdernization: CULTURAL ECONOMIC AND POLITICAL CHANGE IN 43 COUNTRIES (1997). A consistency between cultural norms and societal acceptance of coercive remedial relief should eventually exist over time. See PtTMan B. PotTer, The Economic ConTract LAW OFCHINA: LEGITIMATION AND CONTRACT AUTONOMY IN THE PRC 8 (1992). Culture has been defined as "collective programming of the mind." GEERT HOFSTEDE, CulTuRE's CONSEQUENCES: INTERNATIONAL DIFFERENCES IN WORK-RELATED VALUES 13 (1980). Culture assumes that there is a consistent way of thinking and feeling in a society. Empirical studies have been conducted on the extent to which individual or collective values are held and the degree to which society is acceptant of being directed by government authority. In one study, cultural attributes of the United States, Britain, France, and Germany, were consistent with philosophical premises on which these countries were primarily formed. See id. at 104, 165 , \& 222; see also infra section III; Oscar G. Chase, Legal Processes and National Culture, 5 CARdozo J. INT'L \& COMP. L. 1, 2 (1997); John H. Langbcin, The German Advantage in Civil Procedure, 52 U. CHI. L. REv. 823, 855 (1985).

19. See generally DAMASKA, supra note 11.

20. See id.

21. See id. at 11 .

22. See id. at 80 .

23. What is also unique about the chosen countries is that they are the leading precedential sources that other countries have looked to for legal transplants.

24. See DAMASKA, supra note 11 , at 90.

25. The categorization of semi-active state is not a term that Damaska employed, but is something that the author of this article finds a logical extension of Damaska's framework. Both France and Germany are civil law countries. While contemporary civil law legal systems have been said to have derived from two primary families or branches of law, the Romanic and Germanic branches these two classifications have been fundamentally merged into a single Romano-Germanic civil law model. See KONRAD ZWEIGERT \& HEIN KOTZ, AN INTRODUCTION TO COMPARATIVE LAW (1977); RENÉ DAVID \& JOHN E.C. BRIERLEY, MAJOR LEGAL SYSTEMS IN THE WORLD TODAY (1978).

26. See DAMASKA, supra note 11 , at 12. 
protections ${ }^{27}$ is the notion that vigorous protection of economic rights supports enhanced individualism and a free market economy, ${ }^{28}$ while heightened government control of society and the economy inhibits freedom of contract and mounts barriers to the unabridged protection of property rights. ${ }^{29}$ The historical evolution of the philosophical framework that can be said to most fully sustain economic individualism dawned in England and was transported to the United States. Axioms specified that political affairs generally would succumb to the interests of the private sector ${ }^{30}$ that personal liberty and protection of property was the primary function of public law, ${ }^{31}$ and that liberty of contract "be held sacred." ${ }^{32}$ This can be distinguished from semiactive states that assuredly condone a right to freely dispose of property,${ }^{33}$ but that right is balanced with the public good ${ }^{34}$ curbing transactional freedom..$^{35}$ Additionally, this can be starkly contrasted with the activist states, the former Soviet Union and China, where there was public ownership of all productive resources, ${ }^{36}$ generally no protection of property or economic rights, ${ }^{37}$ and a system of contract that was a public function of the state. ${ }^{38}$ The higher the degree of contractual freedoms and property rights protections institutionally respected in a country, the more difficult it becomes for government actions to deprive holders of those rights from their legal interests.

\section{Derivative Role of the Judiciary}

From these property and contract right conceptions, judicial systems will normally be established in or evolve toward a posture logically supporting the

27. See James Gordley, Contract, Property, and the Will The Civil Law and Common Law Tradition, in THE STATE AND FREEDOM OF CONTRACT 66 (Harry N. Scheiber ed. 1998).

28. See Richard Ely, Property and Contract in Their Rel.ations to the DisTRIBUTION OF WEALTH 53 (1914). The term "market economy" assumes that individual economic actors are permitted to engage in transactions that promote their self-interest in a manner relatively undefiled by government intervention so that forces of supply and demand can establish prices for goods and services in the economy. See id.

29. See DAMASKA, supra note 11 , at 81 . The goals of an activist state could be undermined if individuals could personally profit at the expense of government goals. See id.

30. See Henry Horowitz \& James Oldham, John Locke, Lord Mansfield, and Arbitration During the Eighteenth Century, 36 HISTORICAL J. 137 (1993).

31. See David Lieberman, Contract Before "Freedom of Contract" in ThE STATE AND FREEDOM OF CONTRACT, supra note 27, at 106.

32. Printing and Numerical Registering Co. v. Sampson, L.R. 19 Eq. 462 (1875), quoted in Lieberman, supra note 31, at 112.

33. See R. Pothier, Traité du droit de domaine de propriété, in "Oeuveres de Pothier," cited in James Gordley, Myths of the French Civil Code, 42 AM. J. CoMP. L. 459, 462 (1994).

34. See id. at 463.

35. See SCHLESINGER ET AL., supra note 14, at 734.

36. See WILLIAM G. FRENKEL, COMMERCIAL LAW OF RUSSIA II.A(1) (1995).

37. See George Brunner, The Function of Communist Constitutions: An Analysis of Recent Constitutional Developments, 3 REV. OF SOCIALIST L. 121 (1977).

38. See G.T. Hsiao, The Role of Economic Contracts in Communist China, 53 CAL. L. REV. 1029 (1965). 
predominant ideology of the founding preceptors of the respective countries ${ }^{39}$ and their definition of the apropos relationship between government and citizens, between and among individuals in society. At extremes, judiciaries may remedy ensuing disputes involving legal transgressions in a fashion that is thoroughly encompassing and become enmeshed in the dispute and be influenced by political and ideological forces, or may resolve disputes in a manner that is distant, uninvolved, and not at all impacted by political and ideological pressure. The political and judicial relationship can be situated along a spectrum that ranges from a completely independent judiciary to one that is absolutely subservient to the predilection of political forces. ${ }^{40}$ In the active states, judiciaries have been required to devote weighty deference to state validated prerogatives since court decisions could be monitored and controlled by those with political power ${ }^{41}$ even though judicial independence was commonly alleged. ${ }^{42}$ On the other hand, political fidelity has not been required of judiciaries in reactive states since directing otherwise would question the impartiality of the law and independence and integrity of the judiciary as an institution of government that should have an unbiased decision-making process. Likewise, in the activist states, the judiciary was often employed to preemptively obviate societal disputes from manifesting, while in the reactive states, the judiciary was to provide a remedy "after the fact" ${ }^{43}$ and only to become involved to the extent needed to satisfy the immediate private sector dispute. ${ }^{44}$

Even if a state grants significant power to the judiciary as an independent organ of government and separates policy agendas from the judiciary, it may still substantially restrict its ability to freely rectify disputes in a manner that might diverge with other societal norms. For instance, countries that acclaim property rights and have powerful judiciaries may restrict coercive government

39. This assumes that adequate resources are provided to the judiciary to properly perform the role with which it was endowed. Many developing countries have established certain norms and roles for their judicial branches but because a choice must be made about allocating limited resources, sometimes functions bestowed cannot be discharged. Another issue is that political change in government could also have an important impact on the evolution of the judiciary, although the theme of this work is that the degree of political shift can be somewhat restricted by long-lived and foundational legal sources in a country. For example, individual property rights in the United States Constitution are hailed, while they have been essentially non-existent in China. If later legislation derives from these foundational sources, the legislation cannot egregiously depart from what exists in the foundational source of law, regardless of short-term political shifts.

40. See Jerome Alan Cohen, The Chinese Communist Party and "Judicial Independence": 1949-1959, 82 HARV. L. REV. 967, 972 (1969).

41. See DAMASKA, supra note 11 , at 17.

42. See HAROLD JoSEPH BERMAN, SOVIET CRIMINALLAW AND PROCEDURE 102 (1966).

43. See DAMASKA, supra note 11 , at 73 .

44. See id. at 88. 
authority ${ }^{45}$ and impede any intricate government involvement in the private sector. Reciprocally, if a court system is weak and subordinate to the executive, it may still be endowed with much authority to utilize coercive relief as the remedy of choice, give the non-breaching party exactly what was bargained for in the original contract, and leave damages as a secondary remedy even if a substitutional remedy would objectively and fairly compensate the wronged party. ${ }^{46} \mathrm{~A}$ weak and less independent judicial branch may be accorded with an authority to manage contract performance because the state regards remedial measures as a social institution that endeavors to effectuate moral behavior as a public interest consequence. The type and amount of remedy can punish a wrongdoer ${ }^{47}$ and establish precedent for prospective contractual relations where risk of breach may otherwise be high, and incubate a policy agenda to instill morality in commercial relations. This is not to say that even in countries that traditionally have not been interested in punishing promisors for reneging on contractual obligation ${ }^{48}$ have not done so on occasion for malicious and deliberate breaches, ${ }^{49}$ but this is the anomaly. ${ }^{50}$ Normally only countries that have favored specific performance have also commonly penalized for non-performance. ${ }^{51}$

While the two state extremes discussed above do not exist today, largely because of conflicting forces of market economics and government expansion, examining their historical archetypes and evolutions can portray the coherence between ideologies underlying state formation movements and legal doctrines designed to abet a particular economic ordering. In this economic ordering, there is a theoretical trade-off between control-based/paternalistic government norms and those that promote economic individualism. Principles, norms, and regulations governing contract law are at the essence of societal ordering in any country and the ideology behind that law can generally be traced back to influential and often revolutionary periods over a century ago. The ideology of leaders during influential periods have drastically impacted long-lived and

45. For instance, in the United States, courts are hesitant to employ a court enforced contempt power to coerce actions on defendants. See Douglas Laycock, The Death of the Irreparable Injury Rule, 103 HARV. L. REV. 687, 698 (1990). Giving a court significant coercive power could be inconsistent with a culture that is hesitant to accept government impediments on individual actions.

46. See Arthur Leff, Ignorance and Spite-The Dynamics of Coercive Collection, 80 YALE L.J. 1 (1970).

47. There are also various types of substitutional relief that may have the effect of punishing for breach of contract. Expectation, restitution, and reliance are all damage categorizations. Having rules that favor substitutional relief over specific performance and favor damages that do not require a wrongdoer to forsake ill-gotten gains might even promote breach. See generally RESTATEMENT (SECOND) OF CONTRACTS, ch. 16 (1981).

48. See Oliver Wendell Holmes, The Path of the Law, 10 HARV.L. REV. 457, 462 (1897).

49. See Edward Yorio, In Defense of Money Damages for Breach of Contract, 82 CoLuM L. REV. 1365, 1409 (1982).

50. See Laurence P. Simpson, Punitive Damages for Breach of Contract, 20 OHIOST. L.J. 284 (1959).

51. See Grossfeld, supra note 13, at 1332. 
integral contract law principles and remedial norms for their respective countries. $^{52}$

Having established the theoretical framework of the article in relation to contract and property rights comparisons and the association of the state to the judiciary, a discussion of the historical distinctions in remedial relief follows.

\section{SPECIFIC PERFoRMANCE RULES}

A contract is an agreement whereby parties establish, vary, or terminate relationships and obligations in a manner that did not exist before the contractual relationship was instituted. The parties may have the ability to freely contract in a manner that fully fosters their self-interests, to some degree be restricted by government regulation, or be required to consummate certain terms in their contractual relations. Once the contractual relationship is established and rights and obligations are ascertained, if the contract is irreconcilably breached, the non-breaching (or injured party) has a legal right to enforce that contract or to obtain a substitutional remedial measure in a court system. Inherent in the power of contract is the right to have legal sanctions available that are "adequate to protect reliance on the promise, to prevent gain by default and to effectuate expectations where there may be hidden or unprovable reliance." 53

With specific performance, a court requires that the exact contractual obligation(s) be executed with less ability for the defecting party to maneuver its actions. With substitutional relief, or damages, a contractual obligation is not being coerced, but a court is replacing the original obligation with a substitutional responsibility to pay money. The historical rules concerning which form of relief is favored conspicuously differ across countries.

Revolutionary movements have been the events that have typically induced abrupt alterations in rule/legal frameworks so that there is a "fresh start" regarding legitimate actions of individuals in society, otherwise legal change will normally be more gradual and subject to political transitions and power struggles. Of the states surveyed, it was in the active states (the former Soviet Union and China) where the movement to drastically redefine acceptable societal conduct were most rash, while the semi-active states (France and Germany) incorporated codes to structure future lawful societal behavior in a moderately progressive fashion. The reactive states did not have revolutionary movements beckoning for a more active role for government in society and the economy. In the United States and England, government was

52. The six countries discussed can be seen as precedential and leaders in legal innovation. In many other countries, similar movements have occurred but legal change and the adoption of new norms and codified sources often can be seen as being influenced in some way by these sources (i.e. "legal transplants").

53. See Ian R. MacNeil, Power of Contract and Agreed Remedies, 47 CORNELLL. Q. 495, 497 (1962). 
to promote market transactions, individual rights, and property rights, and norms and rules regarding remedial relief are consistent with these agendas.

\section{A. England and the United States}

\section{Relevant Legal History}

In early England, cultural dominance of localized behavior in unstructured "popular courts" 34 eclipsed attempts to unify the law. A central government and more uniform justice system were eventually forthcoming, but there was never a revolutionary movement in England to call for a more progressive administrative government. In fact, England was not seen as a "modern state" in terms of having institutionally progressive and systematic legislation ${ }^{55}$ since it acclaimed court-made law ${ }^{56}$ and preserved rules of appropriate societal and economic behavior that were most consistent with the current structure and lives of local people. ${ }^{57}$

While some resistance existed to adopting the English common law in the United States, ${ }^{58}$ it was eventually embraced by most American states as their official legal system shortly after the American Revolution, despite an ostensibly ardent intention to disjoin from the British crown and everything associated with it. States and the federal government were hesitant to establish their own codes and/or legislative sources because the predominant American value was that people were to choose their own independent path of social choice and that progressive legislation could hinder that choice. "Government itself was widely viewed as no more than a necessary evil."59 "Both England and the United States affirmed that society and the economy were too complex for government to direct and control ${ }^{60}$ and that government's role should be to encourage "individual creative energy."

The judiciary institutionally reflected a "hands off" approach to dispute settlement since only Courts of Equity, administered by the Chancery, could (1926).

54. See WiLUIAM F. WALSH, OUTLINES OFTHE HISTORY OF ENGLISH AND AMERICAN LAW

55. See DAMASKA, supra note 11 , at 43.

56. This has been the case even though there were futile attempts to replace the common law. See generally FREDERIC WILLIAM MAITLAND, ENGLISH LAW AND THE RENAISSANCE (1901). Likewise, legislation has operated alongside the common law for centuries. See POTTER, supra note 12, at 23.

57. See Nicholas L. Georgakopoulos, Predictability and Legal Evolution, 17 INT'LREV. L. \& ECON. 475, 478 (1997).

58. See WILLIAMF. WALSH, HISTORY OF ANGLO-AMERICAN LAW 93 (2nd ed. 1932); Van Ness v. Pacard, 2 Pet., 27 U.S. 137, 7 L. ed. 374 (1829).

59. See DAMASKA, supra note 11 , at 44.

60. See John V. Orth, Contract and the Common Law, in THE STATE AND FREEDOM OF CONTRACT, supra note 27, at 62.

61. See WiLlaRd J. HURST, LAW AND THE CONDITIONS OF FREEDOM IN THENINETEENTHCENTURY UNITED STATES 7 (1956). 
compel personal conduct, ${ }^{62}$ but courts of general jurisdiction could not. ${ }^{63}$ This jurisdictional archaism was eliminated ${ }^{64}$ but the rules restricting coercive relief over the actions of individuals sojourned in both countries. The historical institutional bifurcation may be a reason specific performance has remained the secondary remedy, ${ }^{65}$ even though courts today have more procedural flexibility to fashion remedial decrees. ${ }^{66}$ Others have claimed that this historical distinction is a "scant justification" for the endurance of such a system. $^{67}$

\section{Specific Performance Rules in England \& the United States}

In the United States "the law of contracts attempts the realization of reasonable expectations that have been induced by the making of a promise." "Reasonable expectations" means that at the time of bargaining, the parties knew that an appropriate remedy would be provided by a court in the event of breach $^{69}$ but it did not necessarily mean that the original promises would be compelled. $^{70}$ The historical institutional limitation was that "courts of equity were without jurisdiction [over a contract dispute] unless the remedy at law was inadequate," making specific performance the exceptional relief in

62. See Sir James O'Connor, Thoughts about the Common Law, 3 CAMB. L.J. 161, 164 (1928); HAROLD D. HAZELTINE, EARLY ENGLISH EQUITY, ESSAYS 261 (1913).

63. See POTTER, supra note 12, at 497.

64. Jurisdictional rules between common law and equity became more uniform. See HENRY LACEY MCCLINTOCK, HANDBOOK OF THE PRINCIPLES OFEQUITY 125-27 (2d ed. 1948). The jurisdictional distinction between these two institutions is only of historical import today since courts of equity were abolished first in the United States in New York in 1848 through the enactment of the Code of Procedure ( $\$ 69)$ and in England in 1873 with the first Judicature Act $(\S 3)$.

65. See E. Allen Farnsworth, Legal Remedies for Breach of Contract, 70 CoLUM. L. REV. 1143, 1151-56 (1970).

66. See Doug Rendleman, The Inadequate Remedy at Law Prerequisite for an Injunction,

33 U. FLA. L. REV. 345, 347 (1981).

67. See E. ALLEN FARNSWORTH, FARNSWORTH ON CONTRACTS, Vol. 3, at 163.

68. See ARTHUR L. CORBIN, CONTRACTS $\$ 2$ (1952).

69. See generally FRIED, supra note 3.

70. There is an often quoted phrase by Justice Holmes that reads:

Nowhere is the confusion between legal and moral ideas more manifest than in the law of contract. . . The duty to keep a contract at common law means a prediction that you must pay damages if you do not keep it and nothing else. . . [S] uch a mode of looking at the matter stinks in the nostrils of those who think it advantageous to get as much ethics into the law as they can.

Holmes, supra note 48 , at 462 .

71. See Harold Greenberg, Specific Performance Under Section 2-716 of the Uniform Commercial Code: "A More Liberal Attitude" in the "Grand Style," 17 NEW ENG. L. REv. 321, 323 (1982). 
England and the United States. ${ }^{72}$ If there was an "adequate remedy at law,"73 coercive relief would be barred and a sum of money would be assessed against the breaching party. ${ }^{74}$ Pleadings would need to exhibit that "reason and conscience" evinced that there were inadequacies in the remedy at law ${ }^{75}$ and that substitutional relief would be exceedingly unfair in lieu of the original performance. $^{76}$

Breach of contract claims can normally be divided into in personam and in rem, whereby, in remedial terms, the former refers to coercing actions of a person and the latter to transferring title to property. ${ }^{77}$ For contracts requiring action by the parties, e.g. service contracts, damages have generally been the expected and only remedy. ${ }^{78}$ When property was the locus of the contract, damages would be inadequate if the plaintiff could not "use them to replace the specific thing he has lost." ${ }^{199}$ For real property, it was assumed that because every parcel of land in the world is unique ${ }^{80}$ specific performance of a land sale contract was required ${ }^{81}$ It would be challenging to find that substitutional relief could not adequately compensate the aggrieved party in the case of personal property since money damages could permit one to purchase comparable goods in the market. However, if a market substitute does not exist, ${ }^{82}$ meaning that the good is unique, ${ }^{83}$ specific relief could be granted.

72. See G.H. Treitel, Remedies for Breach of Contract, in INTERNATIONAL ENCYCLOPEDIA OF COMPARATIVE LAW ch. $16 \S 9$ (1976).

73. See SiR William SEarle Holdsworth, A History of ENGlish LaW, Vol. 1, 457 (7th ed. 1956).

74. See George T. Washington, Damages in Contract at Common Law, 47 L.Q. REV. 345 (1931).

75. See WILliam F. WALSH, WALSH ON EQUTTY 43 (1930).

76. See I.C.F. SPRY, THE PRINCIPLES OF EQUITABLE REMEDIES: INJUNCTIONS, SPECIFC PERFORMANCE, AND EQUITABLE DAMAGES (2nd ed. 1980).

77. See Charles Andrew Huston, The Enforcement of DeCrees In Equity 74 (1915).

78. See Samuel Williston, a Treatise on the Law of Contracts, Vol. $11 \S 1423$ (1968); see Sampson v. Murray, 415 U.S. 61 (1974). Courts would be more apt to prevent the performance of a contract with an injunction. However, there have been situations where courts have enforced affirmative obligations to act, such as with a construction contract, particularly when a high level of supervision is not required by the court. See Tucker v. Warfield, 119 F.2d 12 (D.C. Cir. 1941). M.T. Van Hecke; Changing Emphases in Specific Performance, 40 N.C. L. ReV. 1, 13-16 (1961).

79. See Laycock, supra note 45 , at 703.

80. See Severson v. Elberon Elevator, Inc., 250 N.W.2d 417, 423 (Iowa 1977).

81. See Adderly v. Dixon, 1 Sim. \& Stu. 607, 57 Eng. Rep. 239 (1824); Gethsemane Lutheran Church v. Zacho, 104 N.W.2d 645, 648 (1960); SAMUEL WILLISTON, A TREATISE ON THE LAW OF CONTRACTS $\$ 141,8$ A (3d ed. 1968).

82. See WALSH, supra note 75 , at 301.

83. Economists have defined "uniqueness" in terms of whether there is a "substitutable good" in the eyes of consumer preferences. See Anthony T. Kronman, Specific Performance, 45 U. CHI. L. Rev. 351, 359 (1978). Some examples where this was found include cases involving family jewels (See Duff v. Fisher, 15 Cal. 375 (1860)), customized products (See Cumbest v. Harris, 363 So. 2d 294 (Miss. 1978)), special business interests (See Triple-A Baseball Club Ass'n v. Northeastern Baseball Inc., 832 F. 2d 214 (1st Cir.1987)), and patent 
Even in those circumstances where the locus of the contract would ordinarily imply a need for coercive relief, it could be denied if contract performance would be impossible, unreasonably burdensome, unlawful, or when court orders could be "frustrated by the defendant through exercise of a power of termination or otherwise." 84

All of these situations are premised on court interpretations of the "adequacy of remedy rule" at the reactive common law. The common law rule has been somewhat modified in the case of the sale of goods in both the United States and Britain with the adoption of commercial codes, although Britain seems to have stricter standards. ${ }^{85}$ In the United States, the general policy for the sale of goods is that American courts can order specific performance when it is commercially necessary. ${ }^{86}$ The buyer can obtain specific performance or replevin when the goods are "unique," "inability to cover," when substitutional damages cannot provide adequate relief, or a similar circumstance. ${ }^{88} \mathrm{~A}$ seller can require specific performance of payment of the price when "resale of the goods is impracticable." 89 comparison, under the British Sale of Goods Act, it has been said that the decision to grant specific performance is entirely within the discretion of the court but that it should not be granted when damages would be adequate. ${ }^{90}$ "Only in rare cases do English courts exercise this discretion." B1 Because enacting these codes was a departure from the common law, their application will be discussed in section V(B).

rights (See Corbin v. Tracey, 34 Conn. 325 (1867)). However, even though uniqueness may require coercive relief because of some subjective value, if substitutional relief is granted, there need not be compensation for sentimental or subjective values. See Charles Goertz \& Robert Scott, Liquidated Damages, Penalties and the Just Compensation Principle: Some Notes on an Enforcement Model and a Theory of Efficient Breach, 77 COLUM L. REV. 554, 568-77 (1977).

84. See FARNSWORTH, supra note 67, at 163-64.

85. See U.C.C. \& 2-716; British Sale of Goods Act, 1979, § 52 (Eng.); Jianming Shen, The Remedy for Requiring Performance Under the CISG and the Relevance of Domestic Rules, 13 ARIZ. J. INT'L \& COMP. L. 253, 279-80 (1996).

86. See KENNETH YORK ET. AL., REMEDIES 815 (1985).

87. See U.C.C. \$ 2-716. However, even if this is met, specific performance could be denied if performance were deemed impossible or impracticable (See id. \& 2-615), if a contract defense were available (See Thomas S. Ulen, The Efficiency of Specific Performance: Toward a Unified Theory of Contract Remedies, 83 MiCH L. REV. 341, 396 (1984)), or when parties negotiated out of any right to specific performance (See E. ALLEN FARNSWORTH, CONTRACTS $832(1982))$.

88. See U.C.C. \& 2-716, cmt. 2; see Madariaga v. Morris, 639 S.W.2d 709 (1982).

89. See U.C.C. \& 2-709.

90. See British Sale of Goods Act, supra note 85,852 ; see P.S. ATIYAH, THE SALE OF GOODS 552-53 (1990).

91. Shen, supra note 85 , at 279-80. 


\section{B. France \& Germany}

\section{Relevant Legal History}

Throughout the sixteenth century, European rulers governed much like their reactive state counterparts in that their primary role was that of societal "dispute settler" rather than that of a legislator that framed progressive and objective standards on societal behavior, which was what their role was to become. $^{92}$ It was with revolutionary movements and the adoption of codified law that converted this ideology toward that of a progressive state ${ }^{93}$ that has lasted to this day. ${ }^{94}$

In France, for those living in the generation preceding the 1789 French Revolution, it was a time of economic scarcity for most and a time of opulence for a few. The vast majority of French citizens judged the government to be autocratic, suppressive, corrupt, ${ }^{95}$ a monopolizer of wealth, and endower of special privileges to the allegiant; ${ }^{96}$ while the judiciary was perceived as an inequitable institution that favored property holders and those loyal to the king. ${ }^{97}$ It was this corruption and oppression that drove the French populace into a coup d'état that overthrew the regime. However, unlike the American Revolution, which sought to preserve individual rights against the emergence of a powerful and potentially suppressive government, the French Revolution was aimed at the King and property holders.

Shortly after the Revolution, France began to unify its legal and economic systems in a way that served the needs of the general populace by incorporating public law, granting democratic and individual rights in the 1791 Constitution, ${ }^{98}$ abolishing the ancient system of privileges, ${ }^{99}$ and forming a democratic bond between government and the common person. The fundamental institutional transformation occurred with the 1804 enactment of the French (or Napoléonic) Civil Code, which sought to harmonize law with

92. See Quentin Skinner, The Foundations of Modern Political Thought, Vol. 2,289 (1978).

93. See H.C. GutTERIDGe, Comparative Law: AN INTROduction to THE COMPARATTVE METHOD OF LEGAL STUDY AND RESEARCH 77-78 ( $2 \mathrm{~d} \mathrm{ed}$. 1949).

94. The initial reason for this move may have been a pragmatic desire to hedge against territorial battles and border shifts on the continent since government consolidation and nationalistic movements might more fully unify the country, but the derivative result was progressive government.

95. See Albert GuÉRARd, France: A MOdERn History 233 (1959).

96. See J. Q. C. MACKRELL, THE ATTACK ON 'FEUdALISM' IN EIGHTEENTH CENTURY FRANCE 82 (1973).

97. See id. at 53.

98. These were largely perceived as natural rights. See CHARLOTTEC. WELLS, LAW AND CITIZENSHIP IN THE EARLY MODERN FRANCE 140 (1995).

99. See Francis Deák \& Max Rheinstein, The Development of French and German Law, 24 GEO. L.J. 551, 555 (1936). 
the new societal philosophy ${ }^{100}$ by abolishing feudal hierarchies and property restrictions and sculpting a culture of Frenchmen dedicated to their nation through progressive government statism. ${ }^{101}$ Some have said that this resulted in a culture dedicated to a French way of life and the nation, rather than to a commitment to the private sector, capitalism, and money, which was the case in England and the United States. ${ }^{102}$

Germany undertook a similar approach by employing government progressiveness in the economy and instilling cultural acceptance of those institutions. A national identity movement materialized in Germany by the time the German Reich emerged in 1871 and several new codes were adopted in the next two decades, ${ }^{103}$ but it was the German Civil Code of 1896 that replaced all local laws with a uniform legal system that began to consolidate the country much like that which occurred in France, but without notable violence. ${ }^{104}$ However, unlike France, which had a fairly solid democratic system after its codification period, Germany faced harsh durations of authoritarianism and revolutionary fervor. ${ }^{105}$ From 1933 to 1945 , the centralization and monopolization of authority ${ }^{106}$ dethroned traditional relationships among government, society, and the private sector, so to attune relationships to an authoritarian statist government that planned economic development. ${ }^{107}$ While most private sector enterprises remained legally private in Germany during this period, the government undertook an economic development strategy that was staunchly nationalistic and control-based that dominated interests outside of government. ${ }^{108}$ This persisted after World War II in East Germany, which followed a statist form of rule with a communist/activist legal system like that of the Soviet Union and China, but with the collapse of the Berlin Wall and East Germany's reunification with the corporatist and civil law West Germany in 1989, it then adopted legal, administrative, and political institutions consistent with semi-active state traditions.

100. See Gordley, supra note 33, at 483.

101. See id. at 461.

102. See GUÉRARD, supra note 95 , at 457.

103. Some of the codifications include the 1871 Penal Law, the 1877 Civil Procedure Code, the 1896Private Law, and an 1897 Uniform Commercial Code. See Erhard Blankenburg, Patterns of Legal Culture: The Netherlands Compared to Neighboring Germany, 46 AM. J. COMP. L. 1, 2 (1998). Prior to this period, there were various influences on German law, including the Saxon Civil Code of 1863, the Napoleonic Code, and the Roman Common Law. See Deák \& Rheinstein, supra note 99, at 568-69.

104. See id. at 574.

105. The type of revolutionary movement had the semblance of that which occurred in the Soviet Union.

106. See Reiner Pommerin, Culture in the Federal Republic of Germany 5 (1995).

107. See Marshall Dill, Germany: A Modern History 358-64 (1961).

108. Laws were enacted that said there could be no "unearned incomes" and that there would be "limitations of profits from wholesale operations, land reform, nationalization of all trusts, communalization of all big department stores, and no land speculation." Id. at 299. 


\section{Specific Performance Rules in France and Germany}

In most civil law systems, the right to demand contract performance has been said to be an established principle ${ }^{109}$ and an "absolute right." 110 This is generally the case in France ${ }^{111}$ and Germany, ${ }^{12}$ although German courts have even less discretion to refuse coercive relief than do French courts. ${ }^{113}$ "[T]he sanctity of contract is regarded as implying. . the claim for performance."1/4 Unlike the reactive states, which diluted a court's coercive authority by maintaining non-codified authority restrictions, progressive codified sources in France and Germany presumed that such relief would be granted by a court unless the disadvantages of the remedy outweighed the advantages of granting the relief. ${ }^{115}$

The French Civil Code (FCC) states that contracts have the force of law and must be performed in good faith, ${ }^{116}$ but the innocent party has the ability to choose between specific performance and rescission with substitutional relief. ${ }^{117}$ The choice between remedial measures often favors the one that is most pragmatic for the particular circumstance, ${ }^{118}$ as selected by the innocent

109. See JOHN O. HONNOLD, UNIFORM LAW FOR INTERNATIONAL SALES UNDER THE 1980 UNITED NATIONS CONVENTION 227 (1987). This has generally been the case with all civil law countries influenced by the French and German codes, but with distinctions. See Treitel, supra note $72, \S 12$. For instance, under the Netherlands and Danish law, specific performance is the common remedy (See MiCHAEL. H. WHINCUP, CONTRACT LAW AND PRACTICE 253-54 (1990)), but there is more of a choice between specific and substitutional relief in Spain. See Civil Code of Spain, art. 1124. The Roman law influenced all legal systems on the European continent in many important ways. See SCHLESINGER ET AL., supra note 14, at 221; SYBILLE BEDFORD, THE FACES OF JUSTICE: A TRAVELER'S REPORT 152 (1961). Germany was particularly influenced by the Roman law during the eighteenth and nineteenth centuries. See Dawson, supra note 9 , at 525. However, specific performance is a principle on which France and Germany departed since the Roman law favored substitutional relief. See Neitzel, supra note 2, at 161; SCHLESINGER ET AL., supra note 14, at 219; Dawson, supra note 9, at 496.

110. See Charles Szladits, The Concept of Specific Performance in Civil Law, 4 AM. J. COMP. L. 208, 231 (1955). FCC].

111. See FRENCH CIVIL CODE (J.H. Crabb \& F.B. Rothman, trans.), art. 1184 [hereinafter

112. See GeRman Civil CODE (Forrester, Goren, and Ilgen, trans. of the 1976 Code) [hereinafter BGB]. Provided in Appendix in B.S. MARKESINIS ET AL., THE GERMAN LAW OF OBLIGATIONS: VOLUME I: THE LAW OF CONTRACTS AND RESTITUTION \& 241 (1997).

113. See Szladits, supra note 110 , at 227.

114. See Ulrich Drobnig, General Principles of European Contract Law, in INTERNATIONAL SALE OF GOODS 305 (1986).

115. See Dawson, supra note 9 , at 530.

116. See FCC, supra note 111, art. 434.

117. See id. arts. $1243 \& 1184(2)$.

118. See Dennis Tallon, French Report, in ConTRaCt Law TODAY: ANGLO-FrEnCH COMPARISONS 283 (Donald Harris \& Denis Tallon eds., 1989). 
party or determined by the judge, ${ }^{119}$ but the substitutional remedy can be the only one available if it is the only one still possible. ${ }^{120}$ What is important for comparative purposes is that in France the innocent party has the opportunity and ability to request and attain coercive relief while Britain and the United States have had strict impediments on that remedial choice.

Similarly in England and the United States, it is more difficult to attain a court order compelling a party to do something than to give something ${ }^{121}$ and the FCC similarly demarcates ${ }^{122}$ between obligations to do or abstain from doing something ${ }^{123}$ and obligations to give item(s). ${ }^{124}$ France favors coercive relief for obligations to convey ${ }^{125}$ and to some degree for obligations to $\mathrm{do}^{126}$ even though the general rule code provision, FCC Article 1142, provides that every obligation to do or not to do resolves itself in damages in case of nonperformance. ${ }^{127}$ The codified preference for damages is often discounted and averted because of other provisions and judicial decisions ${ }^{128}$ that do favor coercive relief for personal obligations, ${ }^{129}$ particularly since the intention of this provision was to prohibit excessive coercion on an individual but not to consecrate substitutional relief over specific performance. ${ }^{130}$ Another commentator has stated that an Article 1142 obligation to do should give rise to substitutional relief only when "direct compulsion of the debtor is physically or morally impossible, and there are circumstances where such compulsion would be impracticable or odious." ${ }^{31}$

119. See Szladits, supra note 110 , at 216 . French courts will normally grant specific performance whenever requested by the innocent party unless "costs would be disproportionately high with regard to the damage caused, or where the promisee can have no real interest in receiving specific performance, or the latter would disturb intervening rights of third parties." FCC, supra note 111, art. 1184.

120. See FCC, supra note 111, art. 1184. Courts have leniently interpreted this provision in favor of compelling performance as long as it is still remotely possible. See P.D.V.MARSH, COMPARATIVE CONTRACT LAW: ENGLAND, FRANCE, GERMANY 320 (1994).

121. See G.H. TREITEL, REMEDIES FOR THE BREACH OF CONTRACT 53 (1988).

122. See FCC, supra note 111, art. 1126. A contract to build a boat would be a contract "to do," while a contract to sell an already constructed boat would be a contract "to give." Id.

123. See id. arts. 1142-45.

124. See id. arts. 1136-41.

125. See Dawson, supra note 9, at 524. The legal fiction is that an obligation to convey creates a property right in the transferee at the moment the contract was consummated (See FCC, supra note 111, art. 1138) so for "an obligation to convey," the law attaches, as between the parties, the full and immediate effect of a conveyance. The innocent party has the right to have a bailiff seize the item. See French Code of Civil Procedure, art. 156 [hereinafter FCCP].

126. See MARSH, supra note 120 , at 320 . A commentator at the turn of the century said the "effect of an obligation to do or to abstain from doing is on the other hand in principle restricted to the creation of a right to damages for non-performance." $M$. Sheldon Amos, Specific Performance in French Law, 17 L.Q. Rev. 372, 372 (1901).

127. See FCC, supra note 111 , art. 1142.

128. See Tallon, supra note 118 , at 284.

129. See FCC, supra note 111 , art. 1143.

130. See James Beardsley, Compelling Contract Performance in France, 1 HAST. INT'L \& COMP. L. REV. 93, 93 (1977).

131. See Tallon, supra note 118 , at 285. 
Germany's test for granting coercive relief is rather akin to that of France, but the substantive provisions and powerful German judiciary makes all countries discussed thus far pale in comparison. A patronage for specific performance was clearly foreordained ${ }^{132}$ by the drafters of the carefully thought through and tightly organized ${ }^{133}$ German Civil Code (BGB). The BGB provides that a court can order performance of the original contract terms $\mathrm{s}^{134}$ as long as performance of the original contractual obligation is not impossible ${ }^{135}$ or would not otherwise require unreasonable expense or effort. ${ }^{136}$ "[I]n principle, at least, as long as specific performance enforcement is possible, no damages may be demanded by the promisee for nonperformance of the contract."137 While German courts do have discretion in deciding upon remedial relief, they generally do not refuse specific performance when it is requested. ${ }^{138}$

The BGB specifies that an obligee is entitled to claim performance from the obligor ${ }^{139}$ and that the obligor must "restore the situation which would have existed if the circumstances rendering him liable to make compensation has not occurred," 140 meaning that legal responsibility requires "undoing" the breach. One can request substitutional relief but only after it is pled that specific performance is impossible and a formal demand was made on the obligor to perform according to the original contract terms. ${ }^{141}$ While general provisions strictly favor coercive remedial relief, substitutional relief may be granted even though breach occurred and performance is still possible. For instance, substitutional relief may be granted when performance would now insufficiently compensate the creditor, ${ }^{142}$ if an expected breach is preempted and it is claimed that damages would be the desired remedy when performance does not occur within a reasonable time, ${ }^{143}$ or if specific performance would require a disproportionate expenditure by the obligor to fulfill the originally

132. See Neitzel, supra note 2, at 162 . "[E]very right may be enforced by the courts" and "the purpose of the lawsuit is to create a situation or condition which would exist if no violation or infringement of a right has arisen at all." Id.

133. See Dawson, supra note 9, at 525.

134. See generally B. S. MARKESINIS ET. AL., supra note 112.

135. This form of "impossibility" differs from the case where the obligor should not reasonably be held responsible. See BGB, supra note $112, \S 275(1)$. It is when the obligor can be said to be at least partially responsible for the impossibility that caused the breach (See id. $\$$ 280 ), that the obligor has no reasonable excuse for nonperformance. See TREITEL, supra note 121 at $52-53$.

136. See TREITEL, supra note 121 , at 53 .

137. Szladits, supra note 110 , at 221.

138. See Dawson, supra note 9 , at 530 .

139. See BGB, supra note 112 , at $\$ 241$

140. Id. $\$ 249$.

141. See ERNSt Joseph COHN, MANUAL OF German LaW 105 (1968).

142. See BGB, supra note 112 , at $\$ 251$ Nr. 1

143. See id. $\$ \$ 250,283 \& 326$. The facial rigidity of the rules favoring coercive relief can be pacified when it is clear that damages would be the more efficient and less intrusive remedy. See MARKESINIS ET AL., supra note 134, at 618. 
contracted obligation. ${ }^{144}$ While the BGB is very particular in favoring coercive remedial relief, the German Code of Civil Procedure (ZPO) also has rules that consider distinctive types of contracts.

When goods, assets, land, or other fungible property rights are at issue, specific performance is always available and a court judgment can give the automatic transfer of that property. ${ }^{145}$ While the countries discussed thus far have been more hesitant to grant specific performance for personal performance contracts, in Germany, it is the normal remedy, ${ }^{146}$ particularly when the public interest is involved. ${ }^{147}$ This does not mean that the aggrieved party cannot attain a substitutional remedy when fundamentally necessary, ${ }^{148}$ perhaps by having a third party render performance at the expense of the breaching party ${ }^{149}$ when personal competence is not at issue. ${ }^{150}$

\section{The Soviet Union \& China}

\section{Relevant History}

The period prior to the Russian Revolution of 1917 was an era of tempered private sector, market, and property right freedoms. As the government progressively resorted to direct interference in the economy, such as with "price controls, requisitions, state monopolies, and bans on certain commercial operations," the economy collapsed ${ }^{151}$ and provoked the Russian Revolution, ${ }^{152}$ the abolition of all Czarist laws in $1918,{ }^{153}$ and statist rule over the private sector. ${ }^{154}$ This system embraced the antithesis of reactive state property ownership norms in the reactive states, since the goal was the gradual ${ }^{155}$ "abolition of capitalist ownership and the establishment of public ownership of the basic means of production. . . [and] planned development of

144. See BGB, supra note $112, \S 251(2)$.

145. $\$ \S 894-96$ ZivilproBordnung [German Code of Civil Procedure Statute] [hereinafter ZPO]. The bailiff or police authority can confiscate the goods subject to the court order (See id. $\$ \S 883,884$ ), or evict the breaching party if land is the locus of the contract right (See id. $\S$ 885).

146. See id. $\$ 888$. This includes orders that prevent action. See id. $\S 890$.

147. See MARKESINIS ET AL., supra note 112, at 622.

148. See BGB, supra note 112 , at $\$ 251 \mathrm{Nr} .2$.

149. See ZPO, supra note 145 , at $\$ 888$.

150. See id. $\$ 887$.

151. FRENKEL, supra note 36, at I.A.(13).

152. See KAZIMIERZ GRZYBOWSKI, SOVIET LEGALINSTITUTIONS: DOCTRINES AND SOCIAL FUNCTIONS 28 (1962). The Russian Revolution was said to embrace "the legal ideology of the French Revolution" but it went well beyond ideological change. See id.

153. See generally John N. Hazard, The Future of Codification in the U.S.S.R., 29 TUL. L. REV. 241 (1955).

154. See Dietrich A. Loeber, Plan and Contract Performance in Soviet Law, in LAW INTHE SOVIET SOCIETY 128 (Wayne R. LaFave ed., 1965).

155. See John N. HAZARD, COMMUNists AND Their Law: A SEARch For THE COMMON CORE OF THE LEGal SYSTEMS OF THE MARXIAN SOCIALIST STATES 173-74 (1969). 
the national economy aimed at building socialism and communism."156 Monetary exchange was eliminated, as were contract ${ }^{157}$ and property rights. Nationalizations and expropriations infested the economy. There was a unification between the public and private sectors ${ }^{158}$ and ultimatums initiated in The Five Year Plan to develop the economy. Central planning required state and socialist enterprises to operate economically and according to administrative directives deriving from the central plan and to structure contractual relations consonantly with the plan. "The Soviet state, or more precisely, the Communist Party, maintained a tight economic and political grip on all productive and creative activity through its plenary political powers, and the Soviet law merely acted as a conduit of that political power in replacing market mechanisms with ethereal 'socialist economic relations." "159 The regulatory role of the state over production became complete, unquestioned, and unrelenting, ${ }^{160}$ and was premised on the philosophical collectivist assumption that it was best for the state to define societal interests. This also meant that the judiciary and legal institutions had to be decimated to instill the "socialist concept of justice."161

China, arguably the world's most ancient civilization, traversed five stages of socio-economic and political organization, ${ }^{162}$ but maintained a relatively high degree of social harmony throughout its history chiefly because of paternalistic cultural norms. ${ }^{163}$ Like the Soviet Union, China, starting in 1904 , was also pursuing Western norms of private sector, capitalist, and market order prior to its revolutionary period, including by promulgating new

156. Id. at 6.

157. See V.I. LENIN, SELECTED Works Vol. 9, $288-89$ (1937). While contract law principles were initially abolished, even Lenin later realized that the economy could not function without such principles. See id.

158. See HAZARD, supra note 155 , at 77.

159. FRENKEL, supra note 36, at I.A(16).

160. See id. This was the result even though the initial goal was to reach a stage where no laws or coercion would be necessary. See id. The underlying connection between Marxism and law was that differing economic statuses, particularly between the proletariat and bourgeois, formed a need for law to maintain control over society, but if a classless society existed, formal rigid law would not be needed. See id. It was the "oppression of one class by another" that caused the need for law. See KELSEN, supra note 11, at 52-54. See generally MAUREEN CAIN \& AlAN HUNT, MARX AND ENGELS ON LAW (1979); see also J. W. HARRIS, LEGAL PHILOSOPHIES 251-53; KATHERINE NEWMAN, LAW AND ECONOMIC ORGANIZATION: A COMPARATIVE STUDY OF PRE-INDUSTRIAL SOCIETIES 17-25 (1983).

161. Leaders later realized that more stability and predictability in law was needed. See Joseph Stalin, On the Draft Constitution of the U.S.S.R., 1936, in LENINISM: SELECTED WRITINGS (1942).

162. See Albert Hung-Yee Chen, An Introduction to The Legal System of the PEOPLE'S REPUBLIC OF CHINA 6-7 (1992).

163. See Fu-mei Chang Chen, On Law in Imperial China, 29 HARV. J. OFASIATICSTUDIES 274,275 (1969). 
commercial codes, ${ }^{164}$ but pursuits toward economic Westernization abruptly halted when the Communists ${ }^{165}$ defeated the Nationalists (Kuomingtang) in 1949 in a long and bloody civil war. The Communists abrogated all Kuomingtang laws ${ }^{166}$ and institutions so that political preferences could flexibly direct societal governance in a custom consistent with long-lived paternalist cultural notions. ${ }^{167}$ Expectantly, this also meant severely suppressing property rights and belittling any private sector actions that could oppress the common person or undermine the state's goals. The new Chinese system of governance was based on teachings of Mao and Marx and brought forth an activist and planned economy, ${ }^{168}$ with contractual relations deriving from collectivist planning and policy-making.

\section{Specific Performance Rules in the Soviet Union and China}

The basic rules for specific performance preceding the formation of the Soviet Union were comparable to those in European civil law systems since availability of a "fair substitute" for the locus of a breached contract could sanction the grant of a substitutional remedy. This abruptly changed with the new economic order since decreed planning directives imposed that contracts be executed in a "manner most economical for the socialist economy."169 Since no leniency was procurable in avoiding contractual obligations that derived from a state plan, any discussion of specific performance rules in the former Soviet Union and China must be preceded by a discourse on state planning ultimatums because of the intricate nexus between contract consummation and remedial measures.

Economic actors were required to consummate contracts to fulfill obligations to society in two ways the "administrative legal obligation vis-à-vis the state. . and a civil law obligation between supplier and consumer." 170 Administrative planning restrained the free will of economic actors by mounting parameters for societal action as defined by the will of the government rather than by the will of the individual, which is contrary to the bedrock themes of all countries addressed thus far. This prerogative to control

164. See BEDFORD, supra note 109 , at 153 . While this was certainly a significant departure from the past for China, these codes were said to not live up to Western expectations. See Roscoe Pound, The Chinese Civil Code in Action, 29 TUL. L. REV. 277, 279 (1955).

165. See generally The Legal System of the Chinese Soviet Republic 1931-1934 (W.E. Butler, ed., 1983). The Communist Party of China was founded in 1921 and was ideologically modeled after that of the Soviet Union. See id.

166. See FATHER ANDRE BONNICHON, LAW IN COMMUNIST CHINA 4 (1956).

167. This approach departed from that of the Soviet Union since the Soviets relied more on rigid legalities to nurture its economic modernization program.

168. See generally William Henry Chamberlin, The Soviet Planned Economic ORDER (1931).

169. Russian Soviet Federated Socialist Republic, art. 168, in Soviet CIVIL LEGISLATION (Whitmore Gray \& Raymond Stults eds., 1964) [hereinafter R.S.F.S.R. Civil Code].

170. Loeber, supra note 154 , at 140. 
economic and societal relations was codified and required that the essence of a contract between economic actors be "concluded on the basis of a planned task," "must conform to this task," and that contracts violating economic planning, laws, or "socialist state and society"171 were null and void. ${ }^{172}$ Despite a gradual abatement in the number of production areas and pervasiveness in the economic plans in different periods of communist rule, contracts descending from the plan had to be consummated and exigent obligations of those contracts had to be carried out, making specific performance mandatory, unless there was something that made performance impossible. ${ }^{173}$ Unilateral refusals to perform were not permitted ${ }^{174}$ and creditors could readily demand that debtors transfer specific items that were the subject of a contract. ${ }^{175}$

There were circumstances where attaining an order of specific performance would be less likely. If a contract was consummated and obligations were inconsistent with a planning act ${ }^{176}$ or if a planning act was later altered, then contractual obligations could be expunged. Also, akin to the other legal systems discussed thus far, the probability that performance of personal service contracts would be ordered was lower than in the case of production or sales contracts and could revert to damages, ${ }^{177}$ but because obligations to perform for society prevailed over individual deference and liberties, even personal service contracts could be compelled if needed to accommodate the planning mandate. ${ }^{178}$

China's system of planned economy was premised on the Soviet model and became the foundation and framework by which all in society had to adhere, ${ }^{179}$ which also meant that contracts had to be performed. "As a general rule in Chinese law, the tradition has been to compel the parties to perform their contractual obligations, making the right to specific performance often the primary remedy for breach of contract. Specific performance is even considered a fundamental principle of Chinese contract law." ${ }^{80}$ However, given endemic breaching, ${ }^{181}$ ensuring performance of contracts proved more difficult than expected. ${ }^{182}$ The government met recalcitrance to perform on

171. R.S.F.S.R. Civil Code, supra note 169, art. 49.

172. Principles of Civil Legislation of the Union of the SSR and the Union Republic (1961), in LAW IN EASTERN EUROPE, Vol. 7, 263-98, (1963) [hereinafter PCL].

173. See HAZARD, supra note 155 , at 339.

174. See R.S.F.S.R. Civil Code, supra note 169, art. 169.

175. See id. art. 217.

176. See PCL, supra note 172 , arts. 33 \& 34 .

177. See R.S.F.S.R. Civil Code, supra note 169, art. 218.

178. See HAZARD, supra note 155 , at 321.

179. See Zhonghue Renmin Gonghego Xianfa art. 15 (1962) [Constitution of the People's Republic of China (1962), art. 15, (XIANFA), in ALBERT P. BLAUSTEIN, FUNDAMENTALLEGAL DOCUMENTS OF COMMUNIST [hereinafter PRC Const.].

180. Shen, supra note 85 , at 282.

181. See Hsiao, supra note 38, at 1056.

182. See POTTER, supra note 18 , at 24-25. 
contracts with new penalties and strict fiats about fulfilling economic contract obligations, ${ }^{183}$ pre-emptive measures that established supervisory administrative organs and/or required cadre supervision over contract performance, ${ }^{184}$ and alleged brutalization and reprisals. ${ }^{185}$

While this leads to a very abysmal picture in both the Soviet Union and China, it should be noted that a distinction can be drawn between economic contracts that were derived from the state plan, and civil contracts consummated between private parties that were not so tangentially related to the economic plan. Certainly, the state's interest in permitting coercive relief was highest when the plan was involved, but there was still a tangential effect in civil contracts. Civil contracts did permit more leniency for parties to establish contract terms, but state interest in coercing relief derived more from themes about communal and societal morality than out of pragmatism, which resulted in readily granting specific performance also when there was less state interest involved in the contract at issue.

The unique rules depicted herein, in all three types of states, have since evolved from their historical archetypes. For the most part, only negligible adjustments have occurred in France and Germany, although France did need to produce consistency between the remedial role with which its courts were endowed and their institutional ability to penalize. The next section will philosophically describe why the rules were established as they were, while the section thereafter will explain why seeming shifts have occurred in the interpretation of the rules in Britain and the United States, and why there were drastic overhauls in the Russian and Chinese codified sources covering remedial rules. These rule transitions will be discussed in section $\mathrm{V}$.

\section{Historical IDEOLOGICAL RATIONALE FOR SPECIFIC PERFORMANCE RULE DISTINCTIONS}

At the essence of irreconcilable distinctions in substantive rules to grant specific performance was the foundational ideology on which each state was constituted. Ideological cornerstones ensconced morality norms concerning relations between government and individuals and between economic actors. From this descended the authority of the judiciary and the practical economic manifestation of principles that justified a rule's particular disposition.

183. Circular Concerning the Strict Enforcement of Basic Construction Procedures and the Strict Fulfillment of Economic Contracts (Chinese Central Committee and State Council issued in Dec. 1962) cited in POTTER, supra note 18, at 25-26. The guidelines were designed to penalize and coerce rather than compensate an aggrieved party for losses. See id.

184. See Hsiao, supra note 38 , at $1047,1058$.

185. See generally Fox BUTTERFIELD, ChINA: ALIVE In THE BITTER SEA (1982). 


\section{A. Defining Morality in. Contractual Relations}

There is a stark contrast between how reactive and active states defined morality in contractual relations involving economic actors ${ }^{186}$ and how scholars constituted legal fictions about rights and obligations originating from legally consummated contracts. In the common law states, "rights to remedial relief" are granted to the creditor, while civil law countries perceive the result of contractual relations in terms of obligations owed by a debtor, ${ }^{187}$ and communist systems focused on obligations owed to society. ${ }^{188}$ The differences in these contract law fictions are telling for purposes of portraying how law endows individual right protections versus government ${ }^{189}$ and other individuals, as well as the degree of freedom from government authority provided to the private sector. Practically speaking, any effective remedial system can bestow a self-interest in parties to fulfill contractual obligations since personal morals or fear of disrepute in one's business reputation ${ }^{190}$ alone can succor a self-enforcing mechanism that can curb habitual breaching even when anxiety over legal or government reprisal ${ }^{191}$ does not exist, but it may still be in a government's interest to codify principles that transparently specify a position on contractual morality. ${ }^{192}$

Reactive approaches to law have sought to dispense justice apart from policy agendas of the state. The judiciary is a "promoter and enforcer" of individual rights and liberties, ${ }^{193}$ including against government and majoritarian voices, ${ }^{194}$ connoting that interests of the majority or collective

186. Some scholars have criticized both societal extremes. See generally I. KAWASAKI, JAPAN UNMASKED (1969); ARTHUR BRITTAN, THE PRIVATIZED WORLD (1977).

187. See John Fitzgerald, Recent Developments Relating to CISG: CISG, Specific Performance, and the Civil Law of Louisiana and Quebec, 16 J. L. \& CoM. 291, 302 (1997).

188. See Shen, supra note 85 , at 256 . "Chinese law often emphasizes the [assurance] of performance and addresses remedial issues in terms of the liabilities and obligations of the party in breach rather than strait-forwardly in terms on the remedies and rights of the non-breaching party." Id.

189. See Geoffrey De $Q$. Walker, The Rule of law: Foundations of CONSTITUTIONAL DEMOCRACY (1988).

190. See generally Stewart Macaulay, Non-Contractual Relations in Business: A Preliminary Study, 68 AM. SOCIOL. REV. 55 (1963). The argument is that if one is not concerned about the ethics of fulfilling contractual obligations, one might rationally consider future losses that might be incurred from a smirched business reputation;, as weighed against the benefits that might be provided by a current decision to breach a contract. See generally ANDREW M. SPENCE, MARKET SIGNAUING (1974). This can be perceived as a self-regulatory process or delegation of morality punishable by the market, rather than by government ultimatums of right and wrong. See id.

191. See John H. Wigmore, The Scope of the Contract Concept, 43 COLUM. L. REV. 569, 569-70 (1943).

192. See J. L. MACKIE, ETHICS 116-18 (1977).

193. See Abram Chayes, The Role of the Judge in Public Law Litigation, 89 HARV.L. REv. 1281, 1281 (1976).

194. See AleXander Bickel, The Least Dangerous Branch (1962). 
society can succumb to individual rights ${ }^{195}$ and buttressing the notion that the state should not intricately be involved in the economy or frustrate transactions involving property, contracts, and market competition among private sector actors. Adam Smith wrote that the role of government in the market should be limited and that a natural liberty emerges when man "is left perfectly free to pursue his own interest in his own way," 196 which is a theme espousing that property rights and contractual freedoms should be held inviolable and sacred toward the rest of the world. ${ }^{197}$ This conception of the public good ${ }^{198}$ was translated into and has now evolved into the capitalist structure of social and economic relations ${ }^{199}$ and is the prototype of the reactive government. This form of government that converted "law into rights personal to citizens" ${ }^{200}$ for contract and property, originated in and became accepted conceptually and culturally ${ }^{201}$ in England, ${ }^{202}$ and became the most bedrock legal source in the United States. ${ }^{203}$

195. For a good synopsis of this individual rights/collectivist interest distinction, see generally Randall P. Peerenboom, Rights, Interests, and the Interest in Rights in China, 31 STAN. J. INT'LL. 359 (1995). The ideological struggle endows rights to the side that provides the highest utility. See ROBERT NOZICK, ANARCHY, STATE, AND UTOPIA 30 (1974).

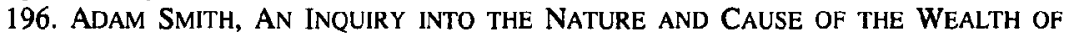
NATIONS (R.H. Campbell, et al., 1976) (1776).

197. See Sir William Blackstone, Commentaries on the LaWs of ENGland 2:2 (1979); see also Printing and Numerical Registering Co. v. Sampson, L.R. 19 Eq. 462 (1875).

198. See A.W.B. Simpson, Land Ownership and Economic Freedom, in THE STATES AND FREEDOM OFCONTRACT 25 (1998). This definition of "public good" runs contrary to what has become the generally accepted, commonplace, and denotative meaning of this term today. See id. Probably the best area in which to ponder this distinction can be found in the conflict between public environmental protections and real property rights. See NiCHOLAS MERCURO ET AL., ECOLOGY, LAW AND ECONOMICS: THE SIMPLE ANALYTICS OF NATURAL RESOURCES AND ENvironmental ECONOMICS 80 (1994); Nancie G. Marzulla, The Property Rights Movement: How it Began and Where it is Headed, in LAND RIGHTS: THE 1990s PROPERTY RIGHTS REBELLION 24 (Bruce Handle ed., 1995); Lynda J. Oswald, Property Rights Legislation and the Police Power, 37 AM. BUS. L.J. 527, 527. For a general description of rights classifications along a private-public continuum, see Robert Bejesky, An Analytical Appraisal of Public Choice Value Shifts for Environmental Protection in the United States \& Mexico, 11 IND. INT'L \& COMP. L. REV. 251, 259-60 (2001).

199. See Harry N. Scheiber, STATE AND FREEDOM OFCONTRACT, supra note 27, at 129-30.

200. DAMASKA, supra note 11 , at 99.

201. See generally Samuel P. Huntington, American Politics: The Promise of DiSHARMONY (1981). Samuel Huntington's American Creed incorporates the ideal of the high value of every individual and that each person has the opportunity and ability to raise himself/herself up to the fullest extent through self-interested individual action, and that government should not interfere, restrain or inhibit individual action. See Martin A. Rogoff, A Comparison of Constitutionalism in France and the United States, 49 ME. L. REV. 21, 38 (1997).

202. See Mark M. Baker, Integration in the Americas: A Latin Renaissance or a Prescription for Disaster, 11 TEMP. INT'L. \& COMP. L.J. 309 (1997).

203. See Scheiber, supra note 199 , at 2 . Not only did this become the "touchstone doctrine by which the constitutionality of various types of social and regulatory legislation was judged," but in economics it meant that the private sector should be free from unreasonable regulation. Id. 
In England and the United States, since the jurisprudential goal of contract law was to satisfy the will ${ }^{204}$ of the individual parties and their right to create a binding legal obligation, ${ }^{205}$ the judiciary was not to employ contract law in a manner that punished breaching parties or instilled moral behavior into the private sector. "The traditional goal of the law of contract remedies has not been compulsion of the promisor to perform on his promise but compensation of the promisee for the loss resulting from breach."206 The remedy should only compensate for the injury suffered ${ }^{207}$ and should not overcompensate the plaintiff. ${ }^{208}$ Obversely, a government favoring compulsive relief assumes institutions must undertake a more profound role in assessing and enforcing contractual fairness because the government has an intricate interest in the private sector.

When a government undertakes a penetrating role in dispute resolution and instills moral norms by assuming the posture that contracts should not be breached, the private sector dispute resolution process is more clearly perceived as a public law function, so not only does breach violate an obligee's rights endowed by an obligor's contractual promises, but there is a perceived spill-over effect on society. This means that individual rights must be more scrupulously balanced against the interests of the general welfare, ${ }^{209}$ which condones relatively more progressive government action in the private sector. This is the position of the semi-active states, and it emerged from a mideighteenth century movement in Europe termed the period of enlightenment and the "age of philosophy." even been said to be directly linked as a cause of the [French] Revolution ${ }^{212}$ and has been claimed to permeate French political thought even to this day. ${ }^{213}$

204. This has been deemed "will theory" and it incorporates the "idea of individual choice and self-determination." Lieberman, supra note 31, at 94 .

205. See P.S. ATIYAH, RISE AND FALL OF FREEDOM OF CONTRACT 399-00 (1979).

206. RESTATEMENT (SECOND), supra note 47 , at ch. 16. Remedies are "aimed at relief to promisees to redress breach." Farnsworth, supra note 65 , at 1147 . "Perhaps it is more seemly for a system of free enterprise to promote the use of contract by encouraging promisees to rely on the promises of others, rather than compelling promisors to perform their promises out of fear that the law will punish their breaches." Id.

207. See Illinois Central Rail Co. v. Crail, 281 U.S. 57, 63 (1930); this is known as expectation damages. See RESTATEMENT (SECOND), supra note $47, \$ 347 \mathrm{cmt}$. a. While other damage awards could grant more to the plaintiff, expectation damages are the normal award and has been said to be the award that promotes "efficient breach." See generally Shavell, Damage Measures for Breach of Contract, 11 BELL J. ECON. 466 (1980).

208. See L. Albert \& Son v. Armstrong Rubber Co., 178 F.2d 182 (2d Cir. 1950).

209. See Charles Hunter Vanduzer, Contribution of the Ideologues to French REVOLUTIONARY THOUGHT 49 (1935).

210. See ERnst CASSIRER, THE PhILOSOPHY OFTHE ENLIGHTENMENT 3 (C.A. Koelln Fritz et al., trans., 1951).

211. See VANDUZER, supra note 209, at 11.

212. See AleXIS De TOCQUEVILLE, THE OLD REgime AND THE Revolution 96 (Alan S. Kahan, trans, 1998).

213. See Rogoff, supra note 201, at 68. 
Natural law theory was the dominant jurisprudential influence on contract and property law doctrines. It professed that government is all powerful and is able to instill social authority and equality for people, ${ }^{214}$ but it also curbed government authority to the degree necessary to ensure that political liberty ultimately resided in the people. ${ }^{215}$ The French Revolution sought to subdue both economic and government oppression, but differed from the American Revolution, which was aimed only at perceived abuses of government authority. ${ }^{216}$ Since the state received power from a collective society and pursued a common endeavor, it had a mandate to progressively act on behalf of the nation to establish parameters in law for moral societal action. Law acquired a public persona ${ }^{217}$ and heartened egalitarian standards in legal doctrines $^{218}$ to undercut hierarchical social structures. ${ }^{219}$ This ideal was codified in the 1791 French Constitution, whereby, a strong republican form of government was incorporated and endowed with power from the collective populace.

The philosophy assisted cooperative vertical relations in terms of establishing a "social contract" between the community and government that permitted the latter to morally guide the people. ${ }^{220}$ A balance was struck between collectivism and individualism ${ }^{221}$ that would more aptly favor social rights when a conflict between the two would arise, ${ }^{222}$ than in the more reactive forms of government. Everyone "places his person and all his power in common under the supreme direction of the general will; and as one we receive each member as an individual part of the whole." 223 A reciprocal commitment between public and private rights ${ }^{224}$ tempered individualism ${ }^{225}$ and provided a social covenant of citizen unity in the populace ${ }^{226}$ to inculcate

214. See TOCQUEVILLE, supra note 212 , at $96-99$.

215. See ChARLES De SECONDAT, BARDON DE L'ESPIRIT DES LOIS (1748), translated in THE SPIRIT OF THE LAWS (1823). Not surprisingly, there were often clashes between contract and property law code provisions and new forms of social regulation. See Gordley, supra note 27 , at 84 .

216. See Rogoff, supra note 201, at 23.

217. See OtTo Gierke, Natural Law and the Theory of Society 1500-1800 36 (Ernest Barker trans., 1957).

218. See generally Michael E. Tigar \& MADEline R. LeVY, LAW aNd the Rise of CAPTTALISM (1977).

219. See generally D. Trubek, Complexity and Contradiction in the Legal Order: Balbus and the Challenge of Critical Social Thought About Law, 11 LAW \& SOC. REV. 529 (1977).

220. See GEIRKE, supra note 217, at 46-50.

221. "Man is born into this world; he neither creates it nor shapes it," and while adaptation to the ideals of the state is expected, some individualism should be asserted as "passive acceptance and obedience have their limits." CASSIRER, supra note 210 , at 18.

222. See generally Rogoff, supra note 201.

223. Jean-JacQues Rousseau, ON the Social Contract 24-25 (Donald A. Cress ed. \& trans., 1983).

224. See id.

225. See DAMASKA, supra note 11 , at 210.

226. See CASSIRER, supra note 210 , at 256. 
confidence in progressive government action. A social contract between government and the people gave rise to a similar principle for horizontal contractual relation $\mathrm{s}^{227}$ in the private sector. ${ }^{228}$

Natural law theory supplanted rival philosophical contract law traditions of the day, ${ }^{229}$ including some versions of "will theory" that sanctified unfettered potential in property holders to do what they wanted with their property ${ }^{230}$ and to freely consummate contracts that would promote this right. ${ }^{231}$ However, when "will theory" was combined with natural law, it was assumed that government intervention was necessary in the private sector to ensure that contracts were fair and not overbearing ${ }^{232}$ on one of the parties ${ }^{233}$ so that individual rights ${ }^{234}$ were protected and property rights institutions served the common good. ${ }^{235}$

Hugo Grotius, the founding father of Dutch law and the most important thinker of the humanist movement, had a conception of a natural law of contracts that said: "promises must be kept, whether [or not] they have been couched in specific form. ... Even God would be acting against his nature [if he] were to not keep his word."236 By comparison, the common law reactive states "approached contract law in terms of the mechanisms for acquiring property title and not in terms of promise-keeping," explained "the rules of contract in terms of the need to secure expectations," and "[repudiated] rival natural law treatments which supposed that 'the contract' required some

227. "Horizontal contractual relations" refer to contracts among economic actors or individuals outside of government. See id.

228. In terms of more fully granting specific performance under natural law and the balance between individual and social rights, a rationale is that because the power to compel performance rests with the judiciary, but rules were established by the legislature and in codes, the judiciary is acting in subordinate to and on behalf of the legislature. See id The power to compel performance of private sector actors is coming from the people. See id. In fact, in Germany, while not adopted in the German Civil Code, there was a proposal to permit courts to adapt the obligations of a private contract "to the requirements of public utility and in accordance with the commands of morals." GRZYBOWSKI, supra note 152, at 39 . Even though this was not adopted, it is telling that such a proposal was made based on philosophical thought and that such a proposal would be inconceivable in Britain or the United States. See id.

229. See Gordley, supra note 27, at 69-70. Natural law departed from earlier philosophical axioms, particularly those based on teachings of Aristotle and Thomas Aquinas. See id. The connection between natural law and a progressive order of the state occurs because "law is [not seen as] simply the sum total of that which has been decreed and enacted; it is that which originally arranges things. It is 'ordering order', not 'ordered order." See CASSIRER, supra note 210 , at 240.

230. See Christopher C. Langdell, Classification of Rights and Wrongs, 19 HARV. L. REV. $537,537-38$ (1900); Gordley, supra note 27 , at 72-76.

231. See id. at 84.

232. Unfairness could result if there were large deviations in consideration. See Gordley, supra note 34 , at 470 .

233. See generally RICHARD ELY, STUdIES IN THE EVOLUTION OF INDUSTRIAL SOCIETY (1903); Roscoe Pound, Liberty of Contract, 18 YALE L.J. 454 (1909).

234. See GRZYBOWSKI, supra note 152 , at 29.

235. See Gordley, supra note 33, at 463.

236. SCHLESINGER ET AL., supra note 14, at 219. 
'original independent reason' for its enforcement other than the general utilitarian justification of private property law."237 The distinction is also one of judicial pragmatism versus theory since "French judges apply a conception of public policy susceptible to philosophic justification . . . whereas . . . English analysts believe that refusal to enforce a contract for public policy reasons is to some extent in conflict with the law rather than in integral union with it."238

The communist principle of morality inaugurated a system that strictly limited individualism so that the interests of the collective society could be elevated. Both the Soviet Union and China believed they could constitute a harmonious society if the state instilled a moral code $e^{239}$ and conducted citizens toward determinations of right and wrong. ${ }^{240}$ "The truly activist state tries to seduce citizens away from private concerns and to mobilize them in pursuit of governmental goals." ${ }^{41}$ Economic law supported this orientation. Since government owned nearly all property, it had the substructure to control or compel what one could do with that property. Even property with scintillas of private ownership were held under the guise that it belonged to the "individual on the strength of the fact that he belongs to the human society. . . [and that property] constitutes a part of the patrimony of all."242 An individual could not use property rights in a way that would harm the community or the socialized economy. ${ }^{243}$ Underlying this theme was that party equality was essential in contractual relations, that market transactions and individual rights ${ }^{244}$ would degenerate law and society, ${ }^{245}$ and that state economic agendas could assure faimess between parties in transactions. ${ }^{246}$ If government guided society, more opportunities and equality would be available to the individual ${ }^{247}$ and rigid legalities protecting "individual rights" would not be necessary. However, both systems out of necessity did incorporate rigid legalities and penalize for societal transgressions, such as breach of contract.

237. JeREMy BenTHAM, THE THEORY OF Legislation 194 (1931), cited in David Lieberman, Contract Before "Freedom of Contract," in THE STATE AND FREEDOM OF CONTRACT, supra note 27, at 102.

238. See HAZARD, supra note 155 , at 325-26.

239. See J. TRISKA, SOVIET COMMUNISM PROGRAMS AND RULES 112 (1962).

240. See Mao Tse-Tung, On the Correct Handung of Contradictions Among the PEOPLE 42 (Eng. trans., 1964).

241. See DAMASKA, supra note 11 , at 153.

242. GRZYBOWSKI, supra note 152 , at 34.

243. See HAZARD, supra note 155 , at 85 .

244. See KELSEN, supra note 11 , at $52-54$. The morality was said to foster freedom from legalities that suppressed the individual since the ultimate goal was to eventually create a classless society that did not require formal law to ensure societal stability. See id.

245. See HAROLD JoSEPH BERMAN, JusticE IN RUSSIA: AN INTERPRETATION OF SOVIET LAW 45 (1950).

246. See GRZYBOWSKI, supra note 152 , at 89.

247. See Raymond Augustine Bauer, The New Man IN Soviet Psychology 2-24 (1952). 
Penalizing for breach, or for any other societal transgression, in the Soviet Union was not intended to be a long-run need, but was conceived to assimilate a culture of people who would devote respect and obedience to the government, legal and social institutions, and the concept of homo sovieticus ${ }^{248}$ through education and reform. ${ }^{249}$ Because economic individualism was nonexistent in the Soviet Union and China, practical problems emerged since economic accountability seemed imperative $e^{250}$ as an adjunct to advancing broader collectivist goals and spontaneous business transactions to stimulate the economy. Penalization for nonperformance became regular and severe, ${ }^{251}$ particularly in the Soviet Union, since aims of criminal and civil justice converged. $^{252}$ While even German courts would regularly assess the willfulness of a breach of contract and punish when breach was more willful and less so when breach was evidently out of the obligor's control, ${ }^{253}$ the level of penalization cannot be compared to that of the Soviet Union and China since assessing fault for determining penalties was regular and more rigid. For instance, if it could be shown that a breaching party "maliciously" broke a contract and that this breach impaired the national economic program, penalties would be more severe and criminalized. ${ }^{254}$ This was the case with the crime of "economic counterrevolution"255 which even led to the execution of a large number of individuals. ${ }^{256}$ Non-fault based breaches were not so harshly penalized. ${ }^{257}$ In the Soviet Union, negligently violating a planning provision could subject "the enterprise to civil suit for damages,"258 while China did not normally criminalize breach of contract but instead subjected those responsible to societal criticism and condemnation ${ }^{259}$ for disrupting the social order. ${ }^{260}$ China did seemingly have a more paternalistic culture that supported societal

248. This means a new Soviet man. See FRENKEL, supra note 36, at I.A(14). The ideal was similar to that which sought to instill French citizenship after the French Revolution, but was premised on an ideology that completely abolished individual rights. See id. at I.A.(14-15).

249. See Grossfeld, supra note 13, at 1332; T. SZABO, THE UNIFICATION AND DiFFERENTIATION IN SOCIALIST CRIMINAL JUSTICE 13 (1978).

250. See Loeber, supra note 154, at 165.

251. See id. at 164.

252. See JoHN N. HAZARD, SETTLING DISPUTES IN SOVIET SOCIETY 401-05 (1966).

253. See Dawson, supra note 9 , at 528.

254. See BERMAN, supra note 42, at 146 . To make this even more severe, these cases were treated as criminal cases that placed the initial burden of proof on the breaching party to show he was not at fault. See HAZARD, supra note 155 , at 322.

255. See id. at 72.

256. See id. at 347.

257. See GROSSFELD, supra note 13, at 1333.

258. See HAZARD, supra note 155 , at 346.

259. See Hsiao, supra note 38, at 1049.

260. Societal condemnation could be more harsh than pecuniary or criminal penalties. This is probably because there was less of a need to indoctrinate a patemalistic culture because China had a long-lived culture more consistent with the new society the communists sought to attain. 
obedience, ${ }^{261}$ which is perhaps why Mao's managerial socialism reached one of the most activist government extremes in the world. ${ }^{262}$

In fact, China can be differentiated from all of the states discussed thus far in that it did not historically have law in the Western sense of the word, or a legal and juridical order codified through intricate textual sources, ${ }^{263}$ as such sources have been few and even non-existent. ${ }^{264}$ Instead, parameters for acceptable societal conduct were premised on cultural norms consistent with deference to government authority. ${ }^{265}$ Moral and cultural norms were "enforced by society instead of government" Confucian philosophy and begot a natural collective identity. ${ }^{267}$ In this order, $l i$ and $f a$ were two terms that depicted the struggle between written legal norms $(\mathrm{fa})$ and "moral rules of correct conduct and good manners" as taught by Confucius $(l i){ }^{268}$ Relying on $l i$, Mao wielded shame as punishment for disrupting the good working order of society, employed Confucian principles of truthfulness and a communal desire for individuals to fulfill obligations to society, ${ }^{269}$ and assigned selfish personal interests in a low priority. ${ }^{270}$ For most of Chinese history, it has not been the dread of judicial coercion or legal punishment that has provided rudimentary favoritism for specific performance as a remedial measure or otherwise stymied breaches from occurring, but societal and cultural norms that made one who disturbed harmony subject to "criticism, self-criticism, demotion, and dismissal."271 Self-interest in China was defined by broader obligations owed to family, friends, and alternative relationships in the collective social order than by individualist notions like

261. See EugEnE EHRLiCh, Fundamental Principles of THE SOCIOLOGY of LAW 373 (1936).

262. See generally P. Heng-Chao-Ch'en, Chinese legal Tradition Under the MONGOLS (1979).

263. See Luke T. Lee, Chinese Communist Law: Its Background and Development, 60 MiCH. L. REV. 439, 439 (1962).

264. See BONNICHON, supra note 166 , at 3.

265. See Chen, supra note 163 , at 275.

266. See Lee, supra note 263 , at 442.

267. See HOFSTEDE, supra note 18 , at 215.

268. See Chang Chin-tsen, Li and Law, 2 Chinese Culture 4, 4 (1960).

269. See Ralph Haughwout et al., Law and Politics of the PEOPLE's Republic of CHINA 335 (1992).

270. See D. Y. F. Ho, The Concept of Man in Mao-Tse-Tung's Thought, 41 PsYCHIATRY 391, 395 (1978).

271. See Hsiao, supra note 38, at 1049. If a cultural foundation exists that is consistent with the state's activist role, one can perceive why excessive legal coercion would not be utilized and would actually be counterproductive since framing societal parameters for right and wrong must be based on societal acceptance. See generally B. I. Schwartz, On Attitudes Toward Law in China, in GOVERNMENT UNDER LAW AND THE INDIVIDUAL (M. Katz ed., 1957). If there is societal acceptance of such norms and they actually cause one to perform on a contract, it would be seen as moral to fulfill one's contractual obligations and understood that harm caused by breach of contract is an abuse on the good-working order of the collective society and not because there is a fear of punishment. See id. Societal shame could provide a greater threat to individual interest than the threat of punishment, legal sanction, or penalty. See id. 
rights, ${ }^{272}$ and it was this self-interest that naturally ensured performance and discouraged breach. ${ }^{273}$

\section{B. Interest of Judiciary}

In dispensing with the obvious interest of the judiciary first prior to examining relative separation of powers attributes, practical judicial concerns endure for remedial relief in every legal system since there is a trade-off between efficiency and exceptional stringency in case supervision. First, emphasis might be placed on efficiency, making a substitutional remedy preferred so that public resources are not expended in monitoring a party's performance. Here, the burden of attaining a satisfactory remedy in terms of the original contract is placed on the non-breaching party. If coercing performance would take much time, energy, and resources away from the court system, or would require tailoring ambiguous contract provisions, then such relief would be less likely, ${ }^{274}$ but would obligatorily still be evaluated within the parameters of each country's remedial relief tests. Second, if coercive relief is freely accorded but mechanisms do not exist to ensure compliance with a coercive court order, e.g. the availability of contempt of court sanctions, ${ }^{275}$ then the integrity of the judiciary as an institution is undermined if orders for specific performance are frequently ignored. In fact, if a judiciary is endowed with notable discretion to decide upon the type of remedial relief, the probability that performance of a court order will be executed by the breaching party might necessarily be pondered by the judge when making the remedial decision. However, even these apparently independent judicial interests are partially derived from the peculiar ideology of the state and the degree that the state has an interest in the affairs of economic actors and in how private sector disputes should be resolved.

Regarding the nexus between the judiciary and the executive, if government empowers the rights of the individual, the judiciary will likely be made a potent ${ }^{276}$ and politically-independent ${ }^{277}$ source to authority ${ }^{278}$ that retains law somewhat more in the sphere of private interests and outside the purview of public interests. The consistency between an institutionally empowered judiciary but one that has restricted remedial authority is clear and can be premised on historical ideals. To permit an institution of government,

272. See generally Ning Fu, Remedies under Chinese Contract Law, 2 INT'LLEG. PERSP. (1990).

273. See Shen, supra note 85 , at 256.

274. See RESTATEMENT (SECOND), supra note 47, § 366; Yonan v. Oak Park Federal Savings and Loan Association, 326 N.E..2d 773 (Ill. App. 3rd 1975).

275. See TREITEL, supra note 121 , at 54.

276. See JoHN P. DAWSON, THE ORACLES OF THE LAW 80 (1968).

277. See generally RICHARD L. ABEL, AMERICAN LAWYERS (1989).

278. See Alexis de Tocqueville, De La Démocractie en Amérique, in PoltTiCal Justice (O. Kirchheimer trans., 1961). 
i.e. the judiciary, to act in a manner that undermines individual free will would be anathema to the detached approach of a state that strives to increase individual rights and ensure against any pretense of government condoned involuntary servitude, ${ }^{279}$ as well as subvert the integrity of an independent judicial branch that is normally respected and hailed for being separate from the branch of government that can most easily suppress individual rights, i.e. the executive. Thus, coercive relief would logically not be the favored remedy in countries with the most respected separation of powers division between the executive and the judiciary, ${ }^{280}$ and in those scenarios where it is granted, harsh penalties to ensure compliance of that award would be unlikely ${ }^{281}$ for the same reasons.

The British and American common law judiciaries have been powerful and respected institutions that reconcile contract contentions without considering particular public policy notions of government, but the "adequacy of damages" remedial test has restrained the authoritative power of the judiciary so that individual rights are not offended and individual court efficiency interests can be encouraged. In these systems, a judge pondering the most appropriate remedial relief will weigh individual rights and whether an order compelling action would unduly encroach on either party's rights or the court's resources and authority, with this decision being very much weighted in favor of substitutional relief because of the "adequacy of damages" screening test. A paradox emerges, since it can logically be contended that discretionary rules permitting more court leniency to determine when specific performance is the more appropriate remedy is a mark of a stronger institution, which has not been the case in Britain and the United States, but this must necessarily be balanced against the elevated nexus between the judiciary and policy-making institutions of government and concomitant subordination to substantive policies that periodically manifest. France and Germany endowed their judiciaries with authority that not only maintains a functional order in the private sector but also with an authority that should promote the public good. ${ }^{282}$ Promoting the public good ${ }^{283}$ meant that

279. See Robert S. Stevens, Involuntary Servitude by Injunction, 6 CORNELL L. Q. 235 , 244-50 (1921).

280. See part III A.

281. See F. LAWSON, REMEDIES OF ENGLISH LAW 9 (2nd ed. 1980).

282. See ARthur Engleman, A History of Continental Civil Procedure 587-15 (1927). Prior to the French Revolution, dispute settlement was designed primarily to serve private rights. See id.

283. Many areas can be comparatively telling as to whether the judiciary promotes the public good and the agenda of the institution. For instance, civil law countries have more fully been concerned with truth-finding in the judicial process (See DAMASKA, supra note 11, at 123) and have been less concerned about expending public resources on the dispute settlement process. See BEDFORD, supra note 109, at 159. 
judiciaries had to be subordinate to codified sources of law ${ }^{284}$ and the central government ${ }^{285}$ since powerful independent judiciaries could otherwise obstruct state reforms or policy measures, ${ }^{286}$ which could be particularly undesirable and undermine the distinct philosophy of the state when policies and laws were democratically made. ${ }^{287}$ France provides a telling example since there was a long-term inconsistency between the judiciary's ability to exercise discretion in employing coercive relief and the fact that it was intentionally made institutionally impotent.

French courts have had substantive authority to grant specific performance, but they were not endowed with any authority to collateralize and ensure that performance would actually occur since empowering the judiciary would subvert the essential theme of the French Revolution. ${ }^{288}$ The court system eventually and independently conceived an invention called astreinte that assessed a monetary penalty on a party for not performing. ${ }^{289}$ However, because the French judiciary was intentionally made weak and subordinate to the state, it could not, by its endowed authority, penalize a party. Thus, astreinte had to be reduced to the "actual loss suffered in consequence of the nonperformance"290 and so once performance occurred, there was no real penalty for non-compliance with a specific performance court order. ${ }^{291}$ The use of this measure and the discrepancy in a substantive codified law that preferred contractual morality but kept the judiciary institutionally weak lasted for nearly two centuries, and it was not until 1972 that French courts were legislatively empowered with an authority to collateralize orders of specific performance ${ }^{292}$ and to penalize for nonperformance. Unlike France, German courts never encountered legal or institutional obstacles in authorizing the use of penalties, such as by using

284. See SCHLESINGER ET AL., supra note 14, at 261. A principle concern of the French Revolution was to usurp the power of the judiciary so that the law would be made "judgeproof." See John Henry Merryman, The French Deviation, 44 AM.J.COMP. L. 109, 109 (1996).

285. See DAMASKA, supra note 11 , at 36.

286. See Stefan Riesenfeld, The French System of Administrative Justice, 18 B.U.L. REV, 48, 56 (1938); see WILLIAM ALEXANDER ROBSON, JUSTICE AND ADMINISTRATIVE LAW: A STUDY OF THE BRITISH CONSTITUTION 229 (2nd ed. 1947).

287. If the law is the will of the people and the will of the people is always correct, then individual judges should not be able to question law that is infallible. See ROUSSEAU, supra note 223 , at 24.

288. See Rogoff, supra note 201, at 23.

289. The counterpart of astreinte is found in most legal systems and is commonly known as a contempt of court order.

290. See Szladits, supra note 110, at 218-20. The astreinte had to be reduced because it could not legally exceed actual damages since French courts did not have a power to penalize.

See Beardsley, supra note 130 , at 96.

291. See Dawson, supra note 9, at 515.

292. Law No. 72-676 of July 5, 1972, France. 
contempt of court fines or even incarceration ${ }^{293}$ to more fully ensure that performance would occur. ${ }^{294}$

Activist state judiciaries were given a mandate to embrace the ideology of the state, ${ }^{295}$ which meant that relatively more coercive relief was justified ${ }^{296}$ to heighten the state ideology $y^{297}$ and ensure that the public good was served by adherence to the state plan. ${ }^{298}$ The judiciary had little to no independence as a fortified branch of government, but was instead subordinate to the state policy-making apparatus. ${ }^{299}$ In the Soviet Union, the state employed the justice system as a tool for policy implementation so that transgressors of the law could be taught lessons ${ }^{300}$ and society at large could be "educated to habits of compliance with the law." ${ }^{301}$ In China, judges were historically seen as agents of the emperor ${ }^{302}$ and their authority was severely limited. ${ }^{303}$ Having a judiciary, as an independent institution of government from a Western connotation appears inconsequential since its role in the more reactive types of state is to represent perceived neutrality and to balance individual rights, but individual rights are instead superceded by the interest of the state and the collective in the activist forms of state. ${ }^{304}$ Both the Soviet Union and China supervised and condoned administrative review of court decisions, ${ }^{305}$ injected state policy into particular disputes, ${ }^{306}$ and usurped jurisdiction in administrative tribunals whenever the government so desired. ${ }^{307}$ Likewise,

293. See MARSH, supra note 120 , at 337.

294. See ZPO, supra note $145, \S 899$.

295. See HAZARD, supra note 155, at 71. In the Soviet Union, the People's Court Act of 1918 directed judges to ignore the former "imperial law" and decide cases based on their "socialist concept of justice." Id.

296. See GRZYBOWSKI, supra note 152, at 39.

297. The Communist Party in China "supplanted the judiciary as an instrument of law." F. SHURMANN, IDEOLOGY AND ORGANIZATION IN COMMUNIST ChINA 180 (1966).

298. In the Soviet Union, a contract dispute between state-run firms fell within the jurisdiction of the Arbitrazh, a special tribunal designed to hear economic cases. See O.S. IOFFE \& P. B. MAGGS, SOVIET LAW IN THEORY AND PRACTICE 306 (1983).

299. For example, courts were completely subordinate to administrative agencies. See Donald C. Clarke, What's Law Got to do with it? Legal Institutions and Economic Reform in China, 10 PAC. BASIN L.J. 1, 66 (1991).

300. This role for the judicial system has been described by Professor Llewellyn as a "parental system." See BERMAN, supra note 245, at 307.

301. DAMASKA, supra note 11 , at 202.

302. See Cohen, supra note 40 , at 968 .

303. See Clarke, supra note 299 , at 57.

304. See Lee, supra note 263, at 449. "Independence" means that "courts must follow the national policy, must be controlled and supervised by the people, and must be in harmony with local government activities." Id.

305. See SHAPIRO, supra note 8, at 180.

306. See DAMASKA, supra note 11 , at 196-97. This political interference was even greater in China than it was in the Soviet system since the CCP regularly interfered with on-going court decisions. See id. at 198-99.

307. See. Loeber, supra note 154, at 131-33. These tribunals were to render justice by considering "community interests, ethical and political interest, and the demands of social justice." See GRZYBOWSKI, supra note 152, at 84 . 
these judiciaries could guarantee orders for performance, ${ }^{308}$ but given the nexus with the executive, this is not surprising and such authority should not be viewed as an independent source of power apart from the executive.

\section{The Practical Economic Consequence of How Morality is Defined}

In the historical reactive states, the assumption was that expanding availability of coercive remedies might result in a slippery slope whereby individual liberty interests could conceivably be compromised and that such a risk was unnecessary if substitutional relief could provide certainty to the contractual bargaining process and sustain a functional market order. The nexus between economics and the common law was what Max Weber deemed a "rational legal system" composed of comprehensive and consistent rules detached from religion, politics, and personal mores, ${ }^{309}$ which by default became driven by private sector pragmatism and economics, rather than by a systematization of law in accordance with a formal or philosophical methodology. ${ }^{310}$ With a limited cultural and institutional acceptance of government jurisdiction over the economy and an inexplicable commitment to protecting property rights, ${ }^{311}$ the government's primary roles were to ensure private sector transactional freedom and bolster self-interested actions of independent economic entities. ${ }^{312}$ Remedies for contract breach became less consequential since the market, based on production from derivative consumer demand, could produce goods with a definite and calculable value ${ }^{313}$ and those fungible goods and services could replace the locus of a breached contract and make substitutional relief substantially equivalent to coercive relief. ${ }^{314}$ The reactive state contract law ideology is sustained by the principles of the modern day law and economics jurisprudential movement, ${ }^{315}$ so it is not surprising that the law and economics influence reemerged in the early 1970 s to counter those who advocated injecting morality into the law and those who

308. See Shen, supra note 85 , at 292. Chinese courts had a weak mandate to penalize. See Clarke, supra note 299 , at 66 . It was often the executive that had to independently support court decisions. See id.

309. See generally Trubek, supra note 219 , at 720.

310. See Dennis Lloyd, Public Policy: A Comparative Study in English and FRENCH LAW 147-49 (1953).

311. See Robert A. Dahl, The American Oppositions: Affirmation and Denial, in POLITICAL OPPOSITION IN WESTERN DEMOCRACIES 35-41 (Robert A. Dahl ed., 1966)

312. This is at the essence of capitalism and market ordering.

313. See HUSTON, supra note 77 , at 74.

314. See Laycock, supra note 45 , at 691.

315. See generally T. ANTHONY KRONMAN \& Richard A. POSNER, THE ECONOMICS OF CONTRACT LAW (1979). 
saw courts imprudently granting coercive relief more often than was necessary. ${ }^{316}$

In the law and economics jurisprudence, punishing for breaching contracts could "stifle the evolution of rules of risk allocation designed to enhance the efficiency of the contract process." ${ }^{\text {317 }}$ Because enhancing allocative efficiency to promote the highest aggregate productivity is the ambition of market ordering, ${ }^{318}$ law should remain neutral so that parties can negotiate and settle disputes in the most efficient manner ${ }^{319}$ without being impeded by legal remedial predispositions or by assigning the burden of assessing the parties' subjective value for the locus of the contract on a dispute settler. If a court becomes more intricately involved and endorses a particular remedial relief, then the personal valuation and the private sector bargaining process can be impaired and increase public expenditures because monitoring costs for the court system can be high ${ }^{320}$ and not achieve the best result from the subjective positions of the parties. If law in the reactive state is intended to support private ends, then minimizing public expenditures by reducing judicial resources and maximizing aggregate production flows is desirable, which can be accomplished by more regularly denying coercive relief as long as the innocent party's rights are protected in any particular individual dispute. ${ }^{321}$ Private sector expectations in the aggregate are still protected. The traditional law and economics contention is that to grant specific performance, "the marginal benefit to the promisee must be sufficiently great that it outweighs the marginal cost imposed on the promisor and on the legal system." 322 The "adequacy of damages" rule ostensibly screens cases to promote this outcome.

316. See Robert L. Birmingham, Breach of Contract, Damage Measures, and Economic Efficiency, 24 RUTGERS L. REV. 273 (1970). Those advocating a more liberal use of coercive relief argued that it would be more efficient than substitutional relief. See Alan Schwartz, The Case for Specific Performance, 89 Y ALE L.J. 271 (1979); see Ian R. MacNeil, Efficient Breach of Contract: Circles in the Sky, 68 VA.L. REV. 947 (1982); see generally Ulen, supra note 87. There are also articles refuting these arguments. See Yorio, supra note 49.

317. Richard A. Posner \& Andrew M. Rosenfield, Impossibility and Related Doctrines in Contract Law: An Economic Analysis, 6 J. LEGAL STUD. 83, 114 (1977).

318. See generally KRONMAN \& POSNER, supra note 315.

319. This is called the "Coase Theorem." See Schwartz, supra note 316, at 277.

320. This should occur if a market economy provides relatively free access to the exchange of goods and services with small friction costs to adequately replace a breached contract and courts do not have to expend public monies to remedy private sector disputes.

321. If no one is harmed and an efficient allocation of resources occurs, then it is said that a Pareto optimal result occurs. See Robert L. Birmingham, Damage Measures and Economic Rationality: The Geometry of Contract Law, DUKE L.J. 49, 55 (1969). However, harm could be forthcoming when significant costs would be necessary to search for a good in the market. See G. STIGLER, THE ORGANIZATION OF INDUSTRY 171-90 (1968).

322. EDWARD YoRIO, CONTRACT ENFORCEMENT: SPECIFIC PERFORMANCE AND INJUNCTIONS $\$ 2.5$ (1989); see David S. Schoenbrod, The Measure of an Injunction: A Principle to Replace Balancing the Equities and Tailoring the Remedy, 72 MINN. L. REV. 627, 636-70 (1988). 
Since France and Germany were more fully incorporated into their economies and have had public and private sectors that have been relatively more closely connected, ${ }^{323}$ self-interest in individual property rights were balanced against preeminent social concerns and gave way to a politicaleconomy structure. There was minimal concern for justifying specific performance rules with economic analysis before the codes were drafted. Since government was expected to act in the economy because of social reliance on such actions, economic efficiency arguments never sallied forth to challenge underlying morality principles of private sector contract performance or to question the government's predominant position when it was a contracting party. ${ }^{324}$

In the activist states, with planned development, contract and property law principles had to be consistent with the state's need to control society and prevent economic actors from engaging in freely negotiated transactions ${ }^{325}$ that might undermine government ultimatums. ${ }^{326}$ Economic plans, which were treated as law, framed parameters ${ }^{327}$ and conditions on which the economy would develop from the top down ${ }^{328}$ and productive sectors at all levels of

323. One of the best examples of this distinction can be found in modern comparative economic thought. American economics has typically employed demand-side economic models, while their Western European counterparts employed supply-side economic models. The former assumes private sector dominance of the economy, while the latter assumes a more intricate government involvement to stabilize the economy. However, the level of integration in both of these categorizations is completely overshadowed by the dominance of the economy and unification between productivity and government and planning approach to development in the former communist countries.

324. An example of how there was relatively more public dominance over the private sector can be illustrated by rules concerning a contract between a private sector entity and a French government agency. If there is a breach of contract, there is a substantial power inequality that favors the French government. See Tallon, supra note 118, at 278-79, 282. Coercive remedies are available to the private sector actor on the government institution pursuant to the civil law, while the government agency has coercive authority over the private sector entity pursuant to the administrative law, which has more lenient specific performance rules. See id. France has never been a "free country" like Britain or the United States when it comes to the ability to challenge government authority. See id.

325. See generally C. HOWE, CHINA's ECONOMY (1978).

326. See DAMASKA, supra note 11 , at 204 . Where the economy is organized by an encompassing plan and the firms are owned by the state, disputes among economic agents cannot be considered in isolation from the overall functioning of the state economy. See id. If problems arise in the preparation and execution of contract among state firms, as administrative perspective on these problems necessarily prevails. See id.

327. See POTTER, supra note 18, at 3-4. The more specific the plan for the economy, the more narrow would be the purview of action available to economic actors and the more expansive would be the limitations on independent initiative. See id. Certain periods of communist rule had stricter and more expansive state plans than did others. See id.

328. Production agendas were established at the top and lower levels had to implement the plans by consummating specific contract terms. See id. 
industry had to adhere to those parameters. ${ }^{329}$ This pragmatically justified the use of specific performance since denying such relief could beget a rippling effect throughout the economy. ${ }^{330}$ Each economic actor in an industrial chain was dependent on all others ${ }^{331}$ to produce for the good of society, ${ }^{332}$ rather than for a profit motive. Money damages could never be an adequate remedy for breach when there was no buyer's market ${ }^{333}$ with available substitutes or pricing mechanisms. ${ }^{334}$ The rules for specific performance, as well as their underlying justifications, were primarily the same in both the Soviet Union and China that economic actors and individuals must perform according to their contractual obligations (and especially when the state economic plan was at issue). The design of the rules sought to engage the people in the beneficent role that the state would nourish by controlling economic relations.

\section{RISE OF THE ADMINISTRATIVE STATE AND ECONOMIC LIBERALIZATION}

While everything to this point reveals how highly disparate were the historical legal frameworks for coercive relief in the event of contract breach, there have been drastic changes in the rules in the former Soviet Union and China and seemingly identifiable deviations in the interpretation of the traditional rule frameworks in Britain and the United States. The position is that the rise of the administrative state in the reactive states and influence of international market economics on the active states pressured remedial rule frameworks and fostered consistency with economic ordering and institutional realities. Of course, other reasons can also partially account for influencing

329. See Elton H. Reiley \& Run-Fu Hu, Doing Business in China After Tiananmen Square: The Impact of Chinese Contract Law and the U.N. Convention on Sale of Goods on SinoAmerican Business Transactions, 24 U.S.F. L. REv. 25, 67 (1989). "[T] he question of concluding a contract is not a private business of the two managers of the socialist enterprises; concluding such a contract is a function of government." BRATUS GENKIN ET AL., SOVETSKOE GRAZHDANSKOE PROVO 397 (1956), cited in GRZYBOWSKI, supra note 152, at 87.

330. See HAUGHWOUT ET AL., supra note 269, at 346.

331. See Grossfeld, supra note 13, at 1330.

The damage to the society as a whole, for example, cannot be compensated, for every breach of contract disturbs a certain established pattern and demands an increased effort to overcome its consequences and re-create order. . Moreover, the goods which could not be produced as a result of the breach of contract are missing in the final balance of the plan, or can be produced only at the expense of other goods.

Id.

332. This was particularly the case when there was only one monopolistic producer of goods.

333. See Michael Gamarnikov, Economic Reforms in EASTERn Europe 12 (1968). It was believed by some that the practical reason for requiring specific performance would become less imperative as markets expanded. See Loeber, supra note 154, at 175. However, chronic shortages remained a problem in China during many periods. See Neil Boyden Tanner, The Yin and Yang of Economic Contract Law in the People's Republic of China B A Legalistic and Realistic Perspective, 16 J. L. \& COM. 155, 155 (1996).

334. See HAUGHWOUT AL., supra note 269 , at 341. 
shifts in judicial authority. While cultural norms beget new ideals about politics and economics and the "globalization of the judiciary" has dispensed more policy-making authority to courts because of the fortification of individual rights and trait sharing between the civil and common law, ${ }^{335}$ ideological country categorizations and motivations that prefer particular specific performance rules have merged and/or become quite congruent ${ }^{336}$ with these alternative explanations of legal evolution.

\section{A. Rise of Administrative State}

The notion of a more assertive and activist state only gradually took hold in the United States and Britain over the past several decades. More progressive government agendas have seemingly modified how courts have interpreted rule frameworks, even though the same legal tests and standards have lingered. Relatively weak government structures existed at the common law and coercive relief was severely restricted, but this evolved incrementally at the same time there was an emergence of more fortified government institutions with progressive proclivities. Government became more involved in the lives of private citizens, which somewhat downplayed notions that completely extolled freedom of contract and secured private property at all costs so to incorporate more public concerns in institutional and policy agendas. The same rationale that sanctioned public utility to supercede individual action can be employed to reveal why courts may have become more apt to render decisions in a manner that previously might have been regarded as undermining individual liberties. ${ }^{337}$

The gradual rise of the administrative state ${ }^{338}$ in Britain and the United States $^{339}$ illustrates a trend moving away from touting individual economic interests at all costs and toward maintaining more parity between state policymaking and individual freedoms. ${ }^{340}$ Not surprisingly, since this rise alleges a separation of powers struggle and departure from long-lived legal principles,

335. See generally THE GLobal EXPANSION OF JUdicial POWER (C. Neal Tate \& Torbjöm Vallinder eds., 1995).

336. See Ole Lando, Article 28 Commentary, in COMMENTARY ON THE INTERNATIONAL Sale Law: The Vienna Sales Convention 233-34 (Cesare Massimo Bianca \& Michael Joachim Bonell eds., 1987).

337. See RichaRd Ely, Studies IN THE Evolution of INDUSTRIAL SOCIETy 400-10 (1903). Similarly, the reactive states became more progressive in protecting weaker parties in a contractual relationship with the emergence of the administrative state. See id. This was not a new theme to United States scholars as many articulated nearly a century ago that inequality in bargaining power was the greatest threat to individual liberties. See id. See generally Roscoe Pound, Liberty of Contract, 18 YALE L.J. 454 (1909).

338. For example, government expansion in the United States primarily took place during the Progressive (1870s), New Deal (1930s), and the Rights Revolution (1960s) eras.

339. See DAMASKA, supra note 11, at 231-32.

340. See Dawson, supra note 9, at 534. 
activist state agendas were met with judicial hesitance in both Britain ${ }^{341}$ and the United States. ${ }^{342}$ New regulatory regimes "came increasingly to be regarded as an instrument for instituting social reform or for challenging existing institutional practices," ${ }^{343}$ and provoked jurisdictional overlaps between administrative tribunals and courts that made their interests adapt to each other, including in the interpretation and enforcement of private contracts. ${ }^{344}$ Once institutional and cultural legal norms ensconced the government itineraries to adopt new legal frameworks or for judges to interpret lingering legal frameworks in a posture that was more acceptant of government initiative in transactions, then perceptions about the acceptability of more involved remedial measures too should also evolve in a direction that is consistent with new progressive institutional or cultural norms.

\section{B. Specific Performance Rule Shifts in Britain and the United States}

Even though common law courts have been said to be more reluctant than their civil law counterparts to "exert pressure directly on the defendant to compel him to perform"345 and to attach property for nonperformance of a specific performance decree, ${ }^{346}$ it appears that the evolution in and application of the British and American specific performance frameworks has made the practical result similar to that of their civil law counterparts ${ }^{347}$ because of efficiency and pragmatism. ${ }^{348}$ It is only what the remedial law and norms express that is a reflection of government ideology regarding private sector relations and whether there is a right to demand coercive relief, even if it is not granted given particular facts, ${ }^{349}$ but it is an aspect of legal culture influencing judicial discretion that may make the outcome of the aggregate of remedial decisions evolve.

Over the past few decades there has not only been advocacy for change ${ }^{350}$ to make coercive remedial relief more readily available than at the common law, but there is evidentiary support that is often given, both because

341. See DAMASKa, supra note 11 , at 43.

342. See Lochner v. New York, 198 U.S. 45 (1905). The trend for the judiciary to start upholding legislation that interfered with private sector contract rights began two years later (See Muller v. Oregon, 208 U.S. 412 (1907)), and was common by 1937. See West Coast Hotel v. Parrish, 300 U.S. 379 (1937).

343. DAMASKA, supra note 11 , at 133.

344. See Scheiber, supra note 199 , at 148.

345. Farnsworth, supra note 65, at 1152; see generally SCHLESINGER ET AL., supra note 14 , at $739-40$.

346. See Szladits, supra note 110 , at 228 . Likewise, an executive official should only execute on a court order to sell the defendant's property as necessary to satisfy the monetary judgment. See HuSTON, supra note 77 , at 7 .

347. See Fitzgerald, supra note 187 , at 302.

348. See HONNOLD, supra note 4, at 277.

349. See Shen, supra note 85 , at 268.

350. See RESTATEMENT (SECOND), supra note $47, \S 359 \mathrm{cmt}$. a. 
of a codified source and evolutionary interpretation of the common law. Commercial codes governing the sale of goods have supplanted long-lived cultural and reflective processes typical of the common law. ${ }^{351}$ In Britain, the adoption of the English Sale of Goods Act endowed courts with elevated discretion in granting specific performance, ${ }^{352}$ making coercive relief in sale of goods contracts more available than at the common law. ${ }^{353}$ Likewise, in the United States, with the adoption of the Uniform Commercial Code (UCC), "specific performance may be decreed where the goods are unique" or "in other proper circumstances." 354 "In other proper circumstances" broadens the common law remedial discretion of courts ${ }^{355}$ and was specifically intended by the UCC drafters to further liberalize the ability of courts to grant specific performance. ${ }^{356}$ It is believed that American courts are more apt to grant specific performance than are English courts ${ }^{357}$ in sale of good cases because the English sales statutes were enacted in the 1890 s, while the UCC was codified in the $1950 \mathrm{~s},{ }^{358}$ making any gradual institutional and progressive trends over time naturally solidified by the ideology at the time of promulgation. ${ }^{359}$

Likewise, even though the institutional demarcation between equity and law has long been eliminated, the test separating the two "adequacy of damages" has remained but has seemingly undergone an interpretive shift. Despite recent holdings by the U.S. Supreme Court that equitable relief is still the extreme case, ${ }^{360}$ trends have been noticed, ${ }^{361}$ and an exhaustive study

351. An important characteristic of the theoretical activist state is that a codified source of law is progressive and structural in nature while the common law is a reflection of the past.

352. See BRITISH SALE OF GOODS ACT, supra note $85, \S 52$.

353. See G.H. TRETTEL, THE LAW OF CONTRACT 906 (8th ed. 1991).

354. See U.C.C. $\$ 2-716(1)$. The definition of when specific performance can be ordered has ostensibly been broadened, from "unique good", to include situations when there is an ambiguous market price. See id. comments 2 and 3.

355. See Stephen Walt, For Specific Performance Under the United Nations Sales Convention, 26 TEX. INT'L L.J. 211, 225 (1991); see U.C.C. § 2-716(1), cmt. 1. Guiding principles in deciding on the type of relief includes: whether the locus of the contract is irreplaceable (see Walt, at 227-28), if damages can be measured with precision, and whether the cost of performance is too high in relation to the plaintiff's benefit. See TREITEL, supra note 121 , at 66 .

356. See John M. Catalano, More Fiction than Fact: The Perceived Differences in the Application of Specific Performance Under the United Nations Convention on Contracts for the International Sale of Goods, 71 TUL. L. REV. 1807, 1818 (1997).

357. See Szladits, supra note 110, at 232.

358. See William Bishop, The Choice of Remedy for Breach of Contract, 14 J. LEGAL STUD. 299, 309 (1985).

359. This assumes that legal codifications in any given period in history acts like a "snapshot" of the political and ideological forces of the day. Culture and other facets may later evolve and place pressures on that "snapshot," perhaps enough so that a new codification must then occur.

360. See Bowen v. Massachusetts, 108 S. Ct. 2722, 2748 (1988) (Justice Scalia stating that the use of equitable relief is reserved for the most extreme cases).

361. See generally Van Hecke, supra note 78. 
recently undertaken that question this premise. ${ }^{362}$ It has been claimed that today the expectations of the parties have a greater impact on what remedial relief is granted than the "adequacy of damages" tes ${ }^{363}$ and that courts have been inclined to interpret the test more flexibly to achieve functional results, ${ }^{364}$ rather than by deciding cases on historical limitations that sought to restrict coercive relief because of potential infringements on individual liberties.

\section{International Economic Integration}

While it was a long-term internal and gradual institutional trend that seemingly paved the way for rule shifts in coercive remedial relief in Britain and the United States, in Russia and China, changes eventuated when these countries recognized that they needed to open their economies to the rest of the world ${ }^{365}$ and were impacted by the effect of globalization. Globalization is caused by catalysts like increases in communication, ${ }^{366}$ technology sharing, ${ }^{367}$ cultural transmissions, ${ }^{368}$ and economic integration. Certainly, a perfect causal relationship between globalization and legal reform cannot be ascribed, ${ }^{369}$ but

362. See Laycock, supra note 45 , at $687-88$. In studying 1400 cases, Professor Laycock concludes that the "adequacy of damages" rule is dead and that plaintiffs get the remedy they choose. See id. In other words, exceptions have "eaten away" at the rigidity of the rule. See $i d$. This is not entirely the case since there are selection effects in choosing only a population of cases that are published since appealed cases are the ones that are most apt to create exceptions from the norm. This does not mean in general that trial courts have discarded the general and long-lived rule. However, Professor Laycock's study is ambitious and may just reflect a temporal trend.

363. See FARNSWORTH, supra note 67 , at $163,168$.

364. See Laycock, supra note 45 , at 693.

365. See John RaPLEY, UNDERSTANDING DEVELOPMENT: THEORY AND PRACTICE IN THE THIRD WORLD 28-29 (1996). For the West, an unprecedented economic integration effort commenced with the Bretton Woods cooperation framework, signed shortly after World War II, and today functions as the bedrock structure for today's nearly universal acceptance of the superiority of freedom of trade, business relations, and financial transactions and is the backdrop that has persuaded governments from remaining self-sufficient and to liberalize their economies. See id. For several decades, the Soviet Union and China provided the antithesis of this theme to the rest of the world. See id. Many Latin American countries also followed an approach of import substitution industrialization policies, that espoused internal production and domestic population needs so to remain free of economic shocks that internationally dependent development could breed. See id. It was with the economic liberalization successes of the Asian Tigers, and the collapse of the Soviet Union's system of central planning at the end of the 1980 s, that the model of closed and government controlled economic development lost credence and support. See id. at 27-50.

366. See Jay R. Mandle \& Louis Ferleger, Preface: Globalization in Southeast Asia, 570 ANNALS OF THE AMER. ACAD. OF POL. \& SOC. SCIENCE 8 (2000).

367. See OFFICE OF TECHNOLOGY ASSESSMENT, MULTINATIONALS AND THE NATIONAL INTEREST: PLAYING BY DIFFERENT RULES 38 (1993).

368. See Gary Minda, Book Review: Globalization of Culture, 71 U. COLo. L. REv. 589, 593 (2000).

369. See Henry Laurence, Symposium, The Rule of Law in the Era of Globalization: Spawning the SEC, 6 IND. J. GLOBAL LEGAL STUD. 647, 648 (1999). 
logic does more than allude that trends in economic globalization can occasion modifications in private sector law, such as with contract law reforms. ${ }^{370}$ Economic integration includes increasing freedom of exchange of currencies, ${ }^{371}$ promoting the benefits of trade, ${ }^{372}$ begetting comparative advantage, ${ }^{373}$ and production efficiencies from that trade ${ }^{374}$ via the General Agreement on Tariff and Trade framework, ${ }^{375}$ and stimulating international investment flows, ${ }^{376}$ including by consummating international agreements on foreign investment. ${ }^{377}$ The obverse result of international market integration is that the role of government in the economy eventually decreases, ${ }^{378}$ an attribute more consistent with the reactive state and shifting power to the private sector. ${ }^{379}$ This shift assumes that government must protect private

370. See Stephen J. Canner, Exceptions and Conditions: The Multilateral Agreement on Investment, 31 CORNELL INT'L L.J. 657, 659 (1998). In 1991, thirty-five countries made eightytwo changes to investment rules, with eighty being liberalizing rules; in 1995 almost "twice as many countries introduced 112 changes in their investment regimes," with 106 of those rules favoring investment liberalization. See id.

371. Articles of Agreement of the International Monetary Fund, 60 Stat. 1401, 2 U.N.T.S. 39 (adopted at Bretton Woods, New Hampshire, July 22, 1944 and entered into force Dec. 20, 1945).

372. What began as an initial step to liberalize trade in goods with the General Agreement on Tariff and Trade, over eight rounds of negotiations has evolved into liberalization in new concerns, such as for trade in services and intellectual property protections, and has provided a more institutionalized dispute settlement forum with the World Trade Organization. See Jagdish BHAGWAIT, A StREAM OF WINDOWS: UNSETTLING ReFlections ON TRADE, IMMIGRATION AND DEMOCRACY 271 (1998). This framework has led to incredible increases in trade. See Mandle \& Ferleger, supra note 366, at 11.

373. See Helen V. Milner \& David B. Yoffie, Between Free Trade and Protectionism: Strategic Trade Policy and a Theory of Corporate Trade Demands, 43(2) INT'L. ORG. 239 (1989), available at http://www.jstor.org/fcgi-bin/jstor/viewitem/fes/00208183/dm980266/ 98p02157/0?current res.

374. See RAPLEY, supra note 365 , at 39-40.

375. General Agreement on Tariffs and Trade, Oct. 30, 1947, 61 Stat. A-11, T.I.A.S. 1700, 55 U.N.T.S. 194, available at 1948 WL 6858.

376. Foreign direct investment has increased dramatically over the years. See United Nations Conference on Trade and Development, World Investment Report, Annex I, II, U.N. Sales No. 97.II.D.13 (1997); see Multinationals, THE ECONOMIST, Mar. 27, 1993, at 5.

377. Over 160 countries have consummated bilateral investment treaties and in 1998 there were more than 1300 agreements ratified globally. See Kenneth J. Vandevelde, Investment Liberalization and Economic Development: The Role of Bilateral Investment Treaties, 36 COLUM. J. TRANSNAT'L L. 501, 503 (1998). This is up from only 435 bilateral investment treaties in 1990. INTERNATIONAL CENTRE FOR SETTLEMENT OF INVESTMENT OF INVESTMENT DISPUTES, BILATERAL INVESTMENT TREATIES 1959-1996, 1-96 (1997). Over thirty countries have signed the Multilateral Agreement on Investment. See Canner, supra note 370, at 659. These agreements do not provide a complete open door policy to investment in host countries as significant limitations still exist (see RICHARD E. CAVES, MULTINATIONAL ENTERPRISE AND ECONOMIC ANALYSIS 222 (1996)), and in some cases "relatively few obligations [are agreed upon by] a host state." Vandevelde, at 522 .

378. This does not mean that government intervention in the economy does not occur in the West, as it does, but such intervention is designed to stabilize rather than to control. See Minda, supra note 368 , at 598-99.

379. See id. at 596. 
property and contract rights, permit the market to allocate resources, and only intervene in the economy to correct market failures. ${ }^{380}$ Cooperative initiatives by governments ${ }^{381}$ and assent to international market principles require domestic contract law regimes to accommodate the many business forms resulting from transnational business operations. ${ }^{382}$ If greater certainty in "global contracting" is to be had, then new remedial rules must be promulgated that are more supportive of norms that sustain individual rights and markets. This is what happened in Russia and China.

\section{Specific Performance Rule Re-Codifications in Russia and China}

Russia somewhat abruptly transformed and China has been gradually modifying domestic legal rules and judicial authority to more fully comport with economic and political realities. At the behest of President Gorbachev's commercial, political, and legal reforms, more of the economy began to operate apart from government authority and law become fairly Westernized. ${ }^{383}$ Since state interest in contractual relations fell with communism and individual rights and markets became a counteracting force, substantive contract law remedial rules and the role of the judiciary needed to be altered.

The Civil Code of the Russian Federation (CCRF) became effective in $1995^{384}$ and new rules were adopted for specific performance that are similar to those of civil law countries. Now, if a party does not give a legally recognized excuse for nonperformance of a contract, then the obligee is entitled to a remedy, with specific performance being the preferred remedy ${ }^{385}$ and there are prohibitions preventing unilateral refusals to perform; ${ }^{386}$ however, there is no state interest in making performance an ultimatum or in severely punishing a breaching party as has previously been the case.

China's gradual release of its economy and opening it up to international market forces over the last two decades and implementation of multiple code

380. See Vandevelde, supra note 377 , at 504-05. The move was a product of the collapse of communism and a shift in economic ideals somewhat away from Kenesian welfare economics to free market principles. See DANIEL Yergin \& Joseph STANISLAw, ThE COMMANDING HEIGHTS: THE BATTLE BETWEEN GOVERNMENT AND THE MARKETPLACE THAT IS REMAKING THE MODERN WORLD 13, 15 (1998).

381. See Paul B. Stephan, Relationship of the United States to International Institutions: The New International Law B Legitimacy, Accountability, Authority, and Freedom in the New Global Order, 70 COLO. L. REV. 1555, 1556-57 (1999).

382. See Linda A. Mabry, Multinational Corporations and U.S. Technology Policy: Rethinking the Concept of Corporate Nationality, 87 GEo. L.J. 563, 575 (1999).

383. See FRENKEL, supra note 36, at I.A(25).

384. See Civil Code of the Russian Federation (ACCRF), adopted by the State Duma at the Third Reading on Oct. 21, 1994, effective Jan. 1, 1995, translated in WILLIAM G. FRENKEL, COMMERCIAL LAW OF RUSSIA (1997).

385. See id. ch. 25 \& art. 309.

386. See id. art. 310. 
sources governing contract law transactions Economic Contract Law (ECL) in $1982,{ }^{387}$ Foreign Economic Contract Law (FECL) in $1985,{ }^{388}$ General Principles of Civil Law (GPCL) in 1987, ${ }^{389}$ and Technology Contract Law (TCL) in $1987^{390}$ confirms how different principles for coercive relief were available depending on the importance of the contractual relationship to government planning and the degree of deference provided to the international system. In 1982, the ECL was adopted to incite a commercial culture that augmented autonomy in economic relations $\mathrm{s}^{391}$ in what was still to officially remain a collectivist and guided system $^{392}$ with government entities monitoring, approving, and remaining ultimately responsible for contracts ${ }^{393}$ to protect public interest. ${ }^{394}$ Economic actors remained under an ultimate mandate to implement the economic plan by consummating and fulfilling contract obligations. ${ }^{395}$ Freedom of contract was restricted by extensive state policy, social morality, public interests, and the economic plan. ${ }^{396}$

All of these codes, except for the FECL, had provisions reflecting the duty to perform in accordance with contract terms, ${ }^{397}$ and is consistent with culture and ideology: "Breach of contract is viewed as a breach of legal duty and is very much discouraged by Chinese law" ${ }^{\prime 398}$ and endows an obligee with the right to demand performance. ${ }^{399}$ The "Chinese principle [is that] specific performance can by no means be replaced by the payment of 'breach of contract' damages." ${ }^{400}$ Not having this remedy specifically listed in the FECL

387. See Economic Contract Law of the People's Republic of China, adopted Dec. 13, 1981 and amended on Sept. 2, 1993, translated in CCH AUSTRALIA LTD., CHINA LAwS FOR FOREIGN BUSINESS (1993) [hereinafter ECL].

388. See Foreign Economic Contract Law of the People's Republic of China, Adopted Mar. 21, 1985, translated in CCH AUSTRALIA LTD., supra note 387 [hereinafter FECL].

389. See General Principles of Civil Law of the People Republic of China, adopted Apr. 12, 1986, by the 4th Sess. Of the 6th National People's Congress, effective Jan. 1, 1987, translated in CCH AUSTRALIA LTD., supra note 387 [hereinafter GPCL].

390. See Technology Contract Law of the People's Republic of China. adopted June 23, 1987 , translated in CCH AUSTRALIA LTD., supra note 387 [hereinafter TCL].

391. See POTTER, supra note 18 , at 30.

392. See ECL, supra note 387, art. 1.

393. See id. art. 44.

394. See CCH InTERnational, China LAW FOR Foreign Business, Rep. No. 6, Feb. 28 , 1994.

395. See ECL, supra note 387 , art. 11 ; see also Shen, supra note 85 , at 296-97.

396. See ECL, supra note 387, art. 1; see GPCL, supra note 389, arts. 6, 7 \& 58; see FECL, supra note 388 , art. 4.

397. See GPCL, supra note 389 , art. 88 ; see ECL, supra note 387 , art. 6 ; see TCL, supra note 390 , art. 16.

398. Zhao Yuhong, Contract Law, in WANG SHENG, INTRODUCTION TO CHINESE LAW 240 (1997).

399. See GPCL, supra note 389, art. 111; see ECL, supra note 387, art. 31; see Zhao, supra note 398 , at 269 . There were also limits to specific performance in Chinese law, including when it would be futile to force an economic actor to perform on a contract (see WILLIAM C. JONES, BASIC PRINCIPLES OF CIVIL LAW IN ChINA 160 (1989)), or when it becomes "impossible" to fulfill the economic contract. See ECL, supra note 387, art. 27).

400. See Shen, supra note 85, at 288. 
characterizes a first and intended distinction between domestic-based contract sources that sought to preserve internal remedial principles and elevated deference to the international system. ${ }^{401}$

With drastic economic reforms in China over the last two decades, all three of the contract law codes were superceded by the Uniform Contract Law in 1999, ${ }^{402}$ which consolidated previous code sources and fostered consistency and greater transparency to China's burgeoning market economy. Increased deference is imparted to international rules and norms of contract law, ${ }^{403}$ but there is still government supervision and approval of contracts ${ }^{404}$ and policies to ensure that China's socialist economic order is maintained, thus abridging free market contracting. ${ }^{405}$ Similarly, there is still emphasis on performance of obligations ${ }^{406}$ and compensation for breach is required, ${ }^{407}$ but there is an ostensible step away from the general policy mandating specific performance since more parameters and limitations on this relief have been ordained. To attain specific performance, coercive relief must be able to be carried out in law and in fact, the object of the debt must be suitable for enforcement, expenses of enforcement must not be too high, and the obligee must have requested that specific performance be ordered within a reasonable time. ${ }^{408}$

\section{E. International Contract Law Negotiations and Specific Performance (UNCISG)}

Because private sector actors desire enhanced certainty in transnational business dealings ${ }^{409}$ and govemments want to foster economic development, an international treaty designed to create more uniformity in contract law was concluded to nourish these aspirations. The Convention on the International Sale of Goods (UNCISG), which now applies automatically to sales contracts consummated between economic actors from two different signatory countries or when it is specifically implicated, ${ }^{410}$ was consummated in 1980 and went

401. The FECL only had provisions that stated that parties should refrain from terminating or altering contractual obligations. See FECL, supra note 368, art. 16. Specific performance could have been permitted as another "reasonable remedy" under the FECL (See FECL, supra note 388, art. 18) since good faith in performance was a guiding principle in the FECL (Zhang Yuqing \& James S. McLean, China's Foreign Economic Contract Law: Its Significance and Analysis, 8 Nw. J. INT'L L. \& BUS. 120, 142 (1987).

402. See Uniform Contract Law of the People's Republic of China, available at http://www.cclaw.net [hereinafter UCL].

403. See id. art. 435.

404. See id. art. 432.

405. See id. arts. $1,3, \& 7$.

406. See id. art. 8.

407. See id. art. 113.

408. See UCL, supra note 402 , art. 116.

409. See Lisa M. Ryan, The Convention on Contracts for the International Sale of Goods:

Divergent Interpretations, 4 TUL. J. INT'L \& COMP. L. 99, 100-01 (1995).

410. See United Nations Convention on Contracts for the International Sale of Goods, U.N. Doc. A/Conf.97/18 Annex 1 art. 1(1) (1980) [hereinafter UNCISG]. 
into effect in $1988 .{ }^{411}$ The negotiations during the Convention depict how very divergent contract law regimes aligned to form a compromise at the international level ${ }^{4 / 2}$ even though negotiated positions adamantly espoused domestic rules. This divergence was particularly the case for rules governing when specific performance should be available. ${ }^{413}$ The position of civil law countries primarily prevailed in the text of the Convention, ${ }^{414}$ presumably because of the sheer number of states following this approach. The United States and United Kingdom argued unsuccessfully that specific performance is an inefficient and burdensome remedy, ${ }^{415}$ while the opposition contended that a non-breaching party should not be required to accept anything less than full performance. ${ }^{416}$ However, the ultimate outcome on this issue does permit flexibility and deference in the domestic interpretation of contract breach remedies governed by the Convention because of significant differences in economic, cultural, and legal norms of countries. ${ }^{417}$

411. See id. The Convention went into effect on January 1,1988 , when it was ratified by eleven nations by December 11,1986 as required by Art. 99 . The first eight countries to ratify were Argentina, Egypt, France, Hungary, Lesotho, Syria, Yugoslavia, and Zambia. See Status of Conventions: Note by the Secretariat 4, U.N. Doc. A.CN.9/271 (1985). On December 11, 1986, China, Italy, and the United States ratified the Convention. See U.N. Dept. of Public Information, Press Release I/T/3849, Dec. 11, 1986.

412. See Amy H. Kastely, Reflections on the International Unification of Sales Law: Unification and Community: A Rhetorical Analysis of the United Nations Sales Convention, 8 J. INT'L L. BUS. 574, 576-77 (1988).

[T] he Convention [was to attempt] to unify the law governing international commerce, [and seek] to substitute one law for the many legal systems that now govern this area" and to unify "the law among nations means to subject people around the world to a single set of rules and principles and to have them understand and conform to these rules and principles as they would to the law of their own communities.

Id.

413. Delegates "struggled to overcome the conceptual barriers of their various national legal backgrounds." See Amy H. Kastely, The Right to Require Performance in International Sales: Towards an International Interpretation of the Vienna Convention, 63 WASH. L. REV. 607, 608-10 (1988).

414. See Olga M. Gonzalez, Remedies Under the U.N. Convention for the International Sale of Goods, 2 INT'L TAX \& BUS. L. 79, 96 (1984).

415. See Kastely, supra note 412, at n. 176. Professor Farnsworth, as a delegate for the United States, argued that specific performance was "too harsh a remedy for breach of an international sales contract." See Kastely, supra note 413, at 628. In an attempt to scratch away at a broad rule that sanctified coercive relief as the remedy of choice, the United States tried to place time limits on both the buyer's and seller's right to demand performance, but this was not accepted by the Committee. See United Nations Conference on Contracts for the International Sale of Goods, Official Records, U.N. Doc. A/Conf./97/19, U.N. Sales No. E.81.IV.3, at 55556,864 (1981) [hereinafter UNCISG Official Records]. Another proposal that was also rejected was to limit the buyer's right to require performance if substitute goods could be obtained "without substantial expense or inconvenience" to the innocent buyer. See id. at. 78, 111.

416. See id. at 328.

417. See Susanne V. Cook, The Need for Uniform Interpretation of the 1980 United Nations Convention on Contracts for the International Sale of Goods, 50 U. PITT. L. REV. 197, 217 (1988). 
In the Convention, specific performance is the remedy of choice ${ }^{418}$ and provisions endow the buyer ${ }^{419}$ and seller ${ }^{420}$ with a right to require a breaching party to perform according to voluntarily undertaken contractual obligations. ${ }^{421}$ However, the broad right to attain coercive relief is limited by practical exceptions typical in domestic legal systems ${ }^{422}$ to preserve sovereignty. ${ }^{423}$ The common law countries specifically requested ${ }^{424}$ that domestic tribunals be permitted to employ the remedial rules of their own jurisdiction even when the Convention was at issue. Pursuant to Article 28 , domestic courts would only be obliged to provide the relief favored in the Convention if they were otherwise required to dispense it under their particular domestic remedial rules, ${ }^{425}$ while the broader scope favoring specific performance in the Convention could still be applied by a court when it would not normally be available under the same circumstance if domestic law was solely at issue.

418. See Kastely, supra note 413 , at 614 . The integrity of the contract should be protected, innocent parties should not be expected to accept something less than full performance, damage determinations would require unnecessary litigation, and obtaining "cover" requires unnecessary costs and delay. See id.

419. "[T]he buyer may require performance by the seller of his obligations unless the buyer has resorted to a remedy which is inconsistent with this requirement." UNCISG, supra note 410 , art. 46.

420. "[T]he seller may require the buyer to pay the price, take delivery or perform his other obligations, unless the seller has resorted to a remedy that is inconsistent with this requirement." ld. art. 62 .

421. Interestingly, the earlier equivalent of the UNCISG, the Uniform Law on the International Sale of Goods, had a broader limit on a buyer's right to demand specific performance, which said:

The buyer shall not be entitled to require performance of the contract by the seller, if it is in conformity with usage and reasonably possible for the buyer to purchase goods to replace those to which the contract relates. In this case the contract shall be ipso facto avoided as from the time when such purchase should be affected.

Uniform Law on the International Sale of Goods, July 1, 1964, 834 U.N.T.S., art. 25.

The difference between the two Conventions may be reflective of how comparative remedial rules have relatively changed in the fifteen years between the adoption of this agreement and the UNCISG, or that the bargaining power and/or number of common law countries involved may have been relatively greater in the earlier convention.

422. A party need not perform if failure to perform was caused by an act or omission of the other party (see UNCISG, supra note 410 , art. 80 ) or by something outside a party's control (See id. art. 79), when a contract is claimed to be void (see id. art. 49), or if denying specific performance is necessary "to prevent punitive and bad faith demands" for coercive relief. Id. art. 7; see Fitzgerald, supra note 187, at 303.

423. See Jacob S. Ziegel, The Remedial Provisions in the Vienna Sales Convention: Some Common Law Perspectives, in INTERNATIONAL SALES: THE UNTTED NATIONS CONVENTION ON CONTRACTS FOR THE INTERNATIONAL. SALE OF GOODS 9-1 (N. Gaston \& H. Smith eds., 1984).

424. See Gonzalez, supra note 414 , at 96.

425. "[A] party is entitled to require performance of any obligation by the other party," but "a court is not bound to enter a judgment for specific performance unless the court would do so under its own law in respect of similar contracts." UNCISG, supra note 410 , art. 28 . The exact meaning of this exception is debatable given that the statement "its own law" could refer to a state's substantive law and/or the state's entire legal system. See Catalano, supra note 356, at 1818 . 
Article 28 reflects a "compromise between civil law countries, which tend to grant specific performance more routinely, and common law countries, which. . . view specific performance as an extraordinary remedy." "426 Even though this exception to the remedial framework was said to be "disruptive [to] the Convention's underlying goal of uniformity," "t27 "threatens extreme uncertainty regarding the right to specific performance," 428 and even undermines the primary goals of the Convention, the importance of this remedial issue to the negotiating countries was so clear that a flexible ultimate outcome was necessary to maintain legal system sovereignty.

\section{CONCLUSION}

This article provided a historical journey through the evolutionary components that have influenced the legal foundation of specific performance, one of the most engrossing concepts in contract law and a remedial issue that is at the essence of judicial authority and government-private sector relations. In a very early form of society where no government existed and dispute settlement incorporated ad hoc mediation methods, a village elder would normally evaluate whether an individual would have a right to the locus of a contract and thus whether that individual would be entitled to exercise selfhelp to attain the item from the current possessor. Practical considerations, such as the inability of the aggrieved individual to cover the loss of contractual expectations, would have logically had to predominate the decision-making process of the dispute settler. Times have changed since economies lacked substitutability for goods and practical concerns no longer mandate the use of specific performance as the only mode of protecting the legitimate expectations of the parties. As Martinus, one of the Four Doctors of Bologna, stated: "if you have sold bread, have not delivered it, and I have died of hunger, will a money judgment suffice." ${ }^{429}$ The existence of markets makes such a concern currently moot.

With the emergence of fortified government institutions and economic exchange, those structuring governance authority will take a position on its role in private sector dispute settlement and the authority that it wants to endow to the judiciary to resolve such disputes. Reactive states, Britain and the United States, structured their economies and societies in a manner that thoroughly promoted individual rights and contractual freedoms. The judiciary is the mainstay of these rights and protects individuals from excessive government intrusions, which has included ensuring that individuals are not subjected to non-essential coercive remedial relief orders for breach of

426. See Walt, supra note 355, at 219.

427. See Gonzalez, supra note 414 , at 98.

428. See Kastely, supra note 413, at 627.

429. HAENEL, DISSENSRONES DOMINORUM 46-48, 93-94, and 597 (1834), cited in Dawson, supra note 9, at 503. 
contract claims. Government institutions have been relatively detached from any intricate involvement in the private sector. However, this remedial system has seemingly gravitated towards more flexible use of specific performance in sale of goods cases with the adoption of the U.C.C., and generally in other types of contract cases at the common law likely because of the foundational expansion of government activity and societal acceptance of that expansion brought about by the piecemeal enlargement of the administrative state.

The semi-active states, France and Germany, had nationalistic and revolutionary movements that resulted in government becoming more involved in the economy and society. Since one can perceive progressive government action and protection of individual conduct on a spectrum, both of these countries cultivated a fairly equal balance between the collective good and individual rights. Likewise, code provisions that sought to fashion societal conduct and thwart disputes from occurring supported this philosophical equilibrium between the collective and the individual. These states had a more pronounced interest in ensuring that morality in contract law abided and functioned for the good of society. This meant that specific performance would be the remedy of choice and that courts should favor compelling performance. Except for the inconsistency between sanctifying coercive relief and the authority of courts in France, this remedial framework has survived with few modifications for nearly two hundred years in France and over a hundred years in Germany. If one rationally assumes that legal evolution occurs because of political and economic change, it is also sensible to conclude that a well-chosen and balanced framework between individual rights and government action would also survive the test of time because it was indicative of what the global system and economies of the world were to become.

The activist states, the former U.S.S.R. and China, underwent abrupt revolutionary movements and adopted an extreme model of government action in the economy and society. Government planning and control over productive entities structured contracts and the law. Since it was imperative that contracts be performed, since not doing so could result in economic production bottlenecks, specific performance became the remedy of necessity. Likewise, the judiciaries in these countries were intentionally made impotent and were agents of the executive branch, primarily so that the collective would not need to succumb to individual rights protections that could disrupt government agendas for the collective. Moral overtones required that one perform on contractual obligations for the good of society. However, because both countries realized that international economic interdependence was essential to long-term development and quality of life, Russia drastically overhauled its economic system and commercial codes, and China has undertaken comparable reforms in a piece-meal fashion. Specific performance rules and norms have also been changed in a manner that is consistent with the struggle between globalization and protecting one's domestic legal sovereignty. 
In short, specific performance remedial rule frameworks and interpretive norms have converged, much like other similar rule frameworks, ${ }^{430}$ as a result of conflicting forces of sovereignty and international integration. Today's multifaceted and economically-integrated world dictates that specific performance be granted when "practically" necessary. ${ }^{431}$ Since a higher percentage of business transactions are of an international nature, countries must be more accommodating when legal system norms depart from those that are more generally accepted in the international system. Legal systems may flexibly adapt to a midpoint location to facilitate elevated ease in international

430. Another area of contract law that depicts consistencies between ideological realities and rule frameworks across countries is that of liquidated damage clauses. In the United States and England, parties are generally free to specify damage amounts to be granted upon a breach of contract (see Anthony Ogus, Remedies: 1. English Report, in CONTRACT LAW TODAY: ANGLO-FRENCHCOMPARISONS (Donald Harris \& Dennis Tallon eds., 1989)), but the legitimacy of such a contract clause depends on whether it was a reasonable pre-estimate of the loss that would be suffered in the event of breach. See Dunlop Pneumatic Tyre Co. v. New Garage, AC 79 (1915). See SCHLESINGER ET AL., supra note 14, at 753. Thus, freedom of contract in predetermining damages is supported unless there are extortionate demands that are reasonable in light of actual loss as a result of the breach. See Paul H. Rubin, Unenforceable Contracts: Penalty Clauses and Specific Performance, 10 J. LEG. STUD. 237 (1981); see MacNeil, supra note 53, at 501-09.

In France, historically, liquidated damage clauses were given full effect regardless of the extremity of the damages mandated by the clause if a breach were to occur. See FCC, supra note 111 , arts. 1226 \& 1152; see Beardsley, supra note 130, at 103 . However, in 1975, this was changed and permitted courts to increase liquidated damage clauses that were ridiculously small or decrease liquidated damage clauses when they were manifestly excessive. See FCC, supra note 111,1975 Amend. to art. 1152. These changes occurred shortly after the astreinte debates in France. In Germany, liquidated damage clauses are payable upon breach (see BGB, supra note $112, \S 339$ ), but courts can increase or decrease amounts that are "disproportionately high." See id. $\$ 340$. There is no such discretion to reduce the amount when merchants are involved. See id. \$ 348 .

In the former Soviet Union, penalty clauses in contracts were not only upheld, but paying them also did not always relinquish contractual obligations. See R.S.F.S.R. Civil Code, supra note 169, arts. $187 \& 191$. When the Soviet Union fell and the CCRF was eventually enacted, penalty clauses could still be applied, but could be reduced if "clearly disproportionate" to the consequences of a violation of an obligation. See CCRF, supra note 384, arts. 330-330. Likewise, legislated penalty clauses were no longer mandated but have been left to the discretion of the contracting parties.

In China, penalty clauses have not only been sustained in favor of the non-breaching party via the contract, but are often prescribed by law. See ECL, supra note 387, art. 31; see FECL, supra note 388 , art. 20 . The obligation to perform could even continue after paying a penalty (see Shen, supra note 85 , at 289 ; see POTTER, supra note 18 , at 33 ) and there are circumstances where both damages and specific performance have been given. See Shen, supra note 85 , at 286-87; see GPCL, supra note 389, art. 34. With the enactment of the new UCL, breaches can be penalized, but China's rules have become more similar to that of Western countries: "[I]f the amount agreed as the costs of the breach greatly exceeds or is much less than the damage that is produced, a party can request the People's Court or an arbitration organization to make an appropriate reduction or increase in the cost." UCL, supra note 402 , art. 118. There are exceptions to this rule on matters in which China seemingly has a more distinctive interest. See id. arts. 355, 356, $362 \& 365$.

431. See Kastely, supra note 413 , at 640. 
contracting. Providing more flexibility to and even revamping rule frameworks has been common since the world has become more interrelated and based on capitalist ideology and market forces. Countries with legal system characteristics that have been furthest from those that have been accepted by the median country have been the ones that have more fully compromised their historical legal frameworks. Legal reforms that amplify predictability have and will continue to materialize and will impact the fate of long-lived legal doctrines, such as that of specific performance. Over time, if economic principles drive legal change, even seminal and enduring legal system characteristics will evolve from various directions to inject or remove underlying themes such as morality or efficiency, and judicial system institutional attributes can evolve to undertake new authorities consistent with evolutionary transformations. ${ }^{432}$ 